\title{
Kentsel Kimlik Bileşenleri ile Yerel Kimliğin İzlerini Sürmek: Kapanca Sokak Örneği
}

\author{
Sonay AYYILDIZ ${ }^{1 *}$, Filiz ERTÜRK²
}

ÖZ

Kentin sahip olduğu kültürel ve doğal değerler, kent kimliğini şekillendirirler. Kent kimlliğinin oluşması için, bu değerlerin sürekliliğinin sağlanması, kentin geçmişinden gelen mesajları geleceğe aktaran maddi ve manevi değerlerin korunması gerekir. Kent kimliğini yansıtan en önemli unsurlardan biri de o kentin tarihi ve mimari özellikleridir. Geçmişte, toplumun değer yargıları ve geleneksel yaşam biçimlerine göre oluşturulan kent yapısının, günümüzde yeni teknolojik gelişmeler, hızlı kentleşme ve nüfus artışı doğrultusunda kentlerin anlam ve kimliğinin sürekli olarak tahrip edildiği görülmektedir. Bu tahrip edilme süreciyle beraber, kentler aynılaşmakta, kentlere ve kent parçalarına karakterini veren ve diğerlerinden ayıran özellik olan 'kimlik' yozlaşmaktadır. Benzer sorunlar Kocaeli kentinde de yaşanmakta; 3000 yıllık tarihi bir geçmişi olan kent, sanayi ve içgöçle beraber kimlik değişimine uğramaktadır. Bu amaçla; çalışmada Kocaeli'nin tarihi kimliğinde önemli bir yer teşkil eden, yüzyılı aşkın tarihi geçmişe sahip olan, özgünlüğünü günümüzde de koruyan ve Kocaeli'nin yerel kimliğinin izlerinin sürülebileceği ender yerleşimlerinden biri olan Kapanca sokağının taşıdığı değerlerin geleceğe iletilebilmesi, kimliğinin ortaya çıkarılması ve kültürel sürekliliğin sağlanabilmesi için kayıt altına alınması gerekliliği düşünülmektedir. Bu çalışmada, Kapanca Sokağının yerel kimliği; doğal, yapay, sosyal çevre ve tarihsel süreç açısından ele alınmış ve incelenmiştir. Böylelikle Kapanca sokağının sahip olduğu özgün tarihsel dokunun gelecek kuşaklara aktarılmasını mümkün kılmak amacıyla, bölgenin değerleri ve geçirdiği değişimler tespit edilmiştir.

Anahtar Kelimeler: Kimlik, Kentsel Kimlik, Yerel Kimlik, Kentsel Kimlik Bileşenleri, Kapanca Sokak

\section{Following of Local Identity Traces through Urban Identity Components: The Case of Kapanca Street}

\begin{abstract}
The cultural and natural values that the city possesses shape the identity of the city. To be formed of the city identity, it is necessary to maintain the continuity of these values and to protect the material and spiritual values that convey the messages of the city's past to the future. One of the most important elements reflecting the urban identity is the historical and architectural features of the city. In the past, the structure of the city, which was formed according to values of society and traditional life styles, has been constantly destroyed in the direction of new technological developments, rapid urbanization and population increase. Along with this destruction, the cities are become the same, the identity that gives characters to the cities and that distinguishes from the others is degenerated. Similar problems are experienced in the city of Kocaeli; The city, which is a historical past of 3000 years, is undergoing identity change with industry and internal migration. Whith this purpose; In order to be able to find out it's identity and provide it's cultural continuity and communicate to the future of the values of Kapanca Street, which is one of the rare settlements in Kocaeli and is an important place in the historical identity of Kocaeli and has a history more than a century and protects its authenticity nowadays and where traces of local identity of Kocaeli can be traced, It is considered necessary to be registered. In this study, local identity of Kapanca Street was investigated in terms of natural, artificial, social environment and historical process. Thus, in order to make it possible to transfer the original historical texture of Kapanca Street to future generations, the values of the region and the changes it has undergone have been determined.
\end{abstract}

Keywords: Identity, Urban Identity, Local Identity, Urban Identity Components, Kapanca Street, Kocaeli

\footnotetext{
${ }^{1}$ Yrd. Doç. Dr., Kocaeli Üniversitesi, Mimarlık ve Tasarım Fakültesi, Mimarlık Bölümü, sonayayyildiz@gmail.com, 05335717631

${ }^{2}$ Yüksek Mimar, Kocaeli Üniversitesi, FBE, Mimarlık Anabilim Dalı, Doktora Öğrencisi ertukk.filiz@gmail.com, 05333714624

*illgili yazar / Corresponding author: Sonay AYYILDIZ, sonayayyildiz@gmail.com
}

Gönderim tarihi: 02.12.2016

Kabul tarihi: 29.05.2017 


\section{GiRiş}

Geçmişten bugüne, insanın var oluşuyla başlayan barınak intiyacı, yine insan eliyle şekillenmiş ve gelişmiştir. Bu gelişme, insanın doğayı, kendisini ve toplumu tanımasıyla var olmuştur. Geçirilen bu süreçler boyunca yapılan yerleşim alanları kendi içlerinde ortak özellikler göstermiş, aynı toplumun ve aynı çevrenin özelliklerini içinde barındırmıştır. Benzer özellikler incelendiğinde ise, o yere özel bir yapı olduğu anlaşılmaktadır. Bu da şüphesiz 'Yerel Kimlik' olarak tanımlanabilmektedir. Yerel kimliği yansıtan en önemli unsurlardan biri de yerin tarihi ve mimari özellikleridir.

Geçmişte, toplumun değer yargıları ve geleneksel yaşam biçimlerine göre oluşturulan kent yapısının, günümüzde yeni teknolojik gelişmeler, hızlı kentleşme ve nüfus artışı doğrultusunda kent anlam ve kimliğinin sürekli olarak tahrip edildiği yönünde eleştiriler bulunmaktadır. Öçal'a (2008) göre; bu tahrip edilme süreciyle beraber, kentler aynılaşmakta, kentlere ve kent parçalarına karakterini veren ve diğerlerinden ayıran özellik olan 'kimlik' yozlaşmaktadır (Bayramoğlu, 2010, s.31-32).

Kaplan'a (1991) göre; zaman içinde toplumların kültürleri, sosyo-ekonomik yaşantıları ve teknolojileri üzerine oluşan değişimler, özellikle yapı çevresi ve sokaklarda hissedilmektedir. Sokaklar, toplumların işlev ve kültür etkileşimi açısından yoğun faaliyet gösterdiği alanlardır (Özalp, 2008, s.21).

Astakoz adı verilen yerde ilk kurulduğu günden bu yana Helen, Roma, Bizans ve Türk uygarlıklarına 3000 yıl boyunca ev sahipliği yapan ve bir zamanlar dünyanın dördüncü büyük kenti (Nikomedia) olan Kocaeli'de sanayinin gelişi ile birlikte kentin tarihi ve kültürel kimliği bozulmaya başlamıştır. Kentin çağlar boyunca geçirmiş olduğu depremler sonucunda da bu uygarlıklardan çoğunlukla günümüze en yakın olan Osmanlı dönemi eserleri ayakta kalabilmiştir. Bunlardan özgün dokusunu koruyabilmiş olan ve kentin yerel kimliğini büyük ölçüde yansıtan Kapanca Sokağı ve konutlarının yok olmadan geleceğe aktarılması önemli görülmektedir.

Bu çalışmada Kapanca Sokağının kimliği, kentsel kimlik bileşenleri ile incelenmiş ve son yüz yıllık tarihsel süreç içerisindeki değişim irdelenmiştir.

\section{KENTSEL KIMLİK VE BİLEŞENLERi}

\subsection{Kent, kimlik ve kent kimliği}

Keleş'e (1976) göre kent, işlevler bütününden oluşmuş bir sosyal sistemdir. Bu sistem birçok ögeden oluşur. Sistemin bütünü insanların arzu ve gereksinimlerinin karşılanması amacına yönelmiştir. Kent sisteminin siyasal, toplumsal, ekonomik ve mekân la ilgili alt sistemleri bulunur (Yayınoğlu ve Susar, 2008, s.11).

Holton'a (1999) göre; Marx, kenti, işbölümü ile özel mülkiyetin karakterize ettiği bütün toplumlarda bulunan özerk bir genel yapı olarak ele almakla; onu, türlü üretim biçimlerinin mülkiyet ilişkilerine göre biçim değiştiren heterojen bir kurum olarak görmek arasında gidip gelmiştir (Yayınoğlu ve Susar, 2008, s.10).

Kent kültür bütününün barındığı ve insan bilinci ve belleğinin yansıması olan zamanın tarih niteliği kazandığı yerdir. İnsanın atasından alıp bir sonraki kuşağa aktardığı değerler ve miras kentte kendini süreklilik içinde ve fiziksel olarak ortaya koyar. Bu bakımdan kentin fiziksel yapısı, yani mimarisi, köprüleriyle, kemerleriyle ev ve anıtları, eski ve yeni mabetleriyle insana dünyanın insan yapısı ve insan mirası olan boyutunu 
anımsatarak, onu geçmişi ve geleceği arasında bir tarihe oturtur ve diğer insanlarla ve kuşaklarla ilişkilendirir (Erzen, s.119).

Proshansky ve Diğerleri'ne (1983) göre; kimlik, yapılan tanımlamalarda genellikle, doğadaki herhangi bir canlıyı veya objeyi diğer canlı ve objelerden ayıran, öncelikle onun görsel, işitsel vb. duygularla algılanan, kendine özgü olma durumu ile ifade edilmekte ve teklik, özgünlük anlamında kullanılmaktadır (Topçu, 2011, s.1052).

İnsanların toplum halinde yaşadıkları, yani bir kültür oluşturdukları her yer ve zamanda, kişi olarak da, toplum olarak da bir kimlikleri olmuştur. 'İnsanlığın kültür ve kimlik gibi olguları kavramlaştırması başka bir kültür/kimlik durumuyla ilk karşılaşma sonrası olmuştur' demek yanlış olmayacaktır. Yani kişi kendi kimliğini ya da kültürünü yaşadığı toplum içinde oluştururken kendi farklıığını ancak başka kimlik ya da kültürle karşılaştığı zaman kavramıştır. Bu farkına varışla birlikte, farklılık bilinci de belirir. Bu anlamda kimlik "kişinin yahut bir sosyal grubun çeşitli mensubiyetlerini açıklayan, onun tanınmasını sağlayan ve dış gözlemle kavranabilen özellikleridir. Kimliği, özneyi en yakın diğerinden ayıran farklılıklar olarak da tanımlayabiliriz." (Kösoğlu, 1995, s.43).

Her insanın kendine ait özellikleri, kimliği ve kişiliği olduğu gibi kentlerin de kendilerine ait kimlikleri vardır. Bu bağlamda kent kimliği; Lynch, (1960); Tekeli, (1990) ve Çöl'e (1998) göre kent imgesini etkileyen, her kentte farklı ölçek ve yorumlarla kendine özgü nitelikler taşıyan, fiziksel, kültürel, sosyo-ekonomik, tarihsel ve biçimsel faktörlerle şekillenen, kentliler ve onların yaşam biçimlerinin oluşturduğu, sürekli gelişen ve sürdürülebilir kent kavramını yaşatan, geçmişten geleceğe uzanan büyük bir sürecin ortaya çıkarttığı anlam yüklü bütünlüktür (Topçu, 2011, s.1052).

Kentin sahip olduğu kültürel ve doğal değerler, kent kimliğini şekillendirirler. Kent kimliğinin oluşması için, bu değerlerin sürekliliğinin sağlanması, kentin geçmişinden gelen mesajları geleceğe aktaran maddi ve manevi değerlerin korunması gerekir. Kentin farklı dönemlerine tanıklık etmiş yapılar ve yapı grupları, kentlilerin yaşantısına dahil olarak sözü edilen değerler içerisinde öncelikli konumda yer alırlar. Bu nedenle bir kentte o kentin özgün kimliğine katkısı bulunan ve ait olduğu döneme ilişkin kayda değer mimari ve yaşamsal özellikler taşıyan yapıların korunması, o kentte kültürel sürekliğin sağlanmasında ve kentin kimliğinin oluşumunda ve oluşmuş kimliğin geleceğe taşınmasında önemli bir rol oynar (Birol, 2007, s.46-54).

Kent kimliği, bir kenti diğerlerinden ayıran özellikler bütünü olarak özetlenebilir ve birçok bileşenin bir araya gelmesiyle oluşur. Her kentin sahip olduğu coğrafya ve insan topluluğu farklıdır. Bu nedenle bu farklııkların mimari mekânlara yansıması da farklıdır.

\subsection{Kentsel kimlik bileşenleri}

Önem ve Kılınçaslan'a göre, kentlerin farklı karakterleri kent kimliği, kent profili ve kent imgesi kavramlarıyla açıklanmaktadır. Kent kimliği uzun bir zaman dilimi içinde biçimlenir. Kentin coğrafi içeriği, kültürel düzeyi, mimarisi, yerel gelenekleri, yaşam biçimi, niteliklerin karışımı olarak kente biçim verir. Kentin profilini doğal profili, sosyoekonomik profili ve insan eliyle yapılmış mekânın profili ile bir bütünleşmenin değerlendirilmesi oluşturur. Kent kimliğini oluşturan elemanlar doğal, beşeri ve insan eliyle yapılmış çevreden kaynaklanan elemanlar açısından değerlendirilebilir (Önem ve Kılınçaslan, 2005, s.116).

Liggett ve Perry'ye (1995) göre; doğal çevreden kaynaklanan kimlik unsurları, kentin topoğrafik durumu, iklim koşulları, bitki örtüsü, genel konumu vb. özellikleridir. Beşeri 
çevreden kaynaklanan kimlik unsurları, birey ve toplumdur. Bireylerin ve toplumun sahip olduğu değerler, kimliklerini oluşturur ve bu değerler kent kimliği ile doğrudan ilişkilidir. İnsan eliyle yapılmış çevreden kaynaklanan kimlik unsurları ise; kentte yapılmış olan her türlü düzenlemenin özellikleridir. Bu düzenlemeler içerisinde kentteki meydanlar, sokaklar, anıtlar vb. her türlü kentsel bileşen yer alabilir (Yayınoğlu ve Susar, 2008, s.10).

Kent her şeyden önce anlaşılabilir ve okunabilir olmalıdır. Okunabilen bir kent, mahalleleri, odak noktaları veya yolları kolayca ayırt edilebilen ve basit bir şekilde gruplandırılabilen kenttir. Anlaşılabilirlik ve okunabilirlik, güzel bir şehrin tek başına önemli özelliği olmamasına rağmen, kentsel ölçekte boyut, zaman ve karmaşıklığa sahip çevreler göz önüne alındığında özellikle önemli olmaktadır (Lynch, 2014, s.3).

Bir kentin kimliği; doğal ve yapay çevreden kaynaklanan kimlik elemanları, bu elemanların mekânsal öğeleri, tarihi, kültürel değerleri ve düzeyi, mimarisi, sosyal yapısı, coğrafyası, içinde yaşayan uygarlıkları, yerel gelenekleri, yaşam biçimi, şu anda yaşayan insanları, ilk yerleşimden bugüne geçirdiği evreleri, topografyası, bitki örtüsü, iklimi, jeopolitik konumu, Doğu veya Batı kenti oluşu, deniz ve karayolu bağlantısı, başka kültürlere olan açıklığı veya kapalıığı, ekonomik yapısı, barındırdığı canlı türleri, geçirdiği işgaller ve savaşlar, depremler, bir devlete başkentlik yapıp yapmadığı vb. birçok etken ile değişebilmekte ve böylelikle kendine has özellikler kazanmaktadır. (Kösoğlu, 1995, s.43).

Yerleşme özellikleri ne olursa olsun yapıların diğer yapılar ile birlikte var olduğu ve doğada doğal koşullar ile birlikte yer aldığı gerçeği göz ardı edilemez. Yerleşmeyi oluşturan yapıların bir araya gelme biçimleri bir yandan yapıların kendi iç-mekân sal kurgularını etkilerken, diğer yandan da yerleşmelerin karakterlerinin oluşmasında etkili olmaktadır (Eyüce, 2005, s.23).

Kent kimliğini oluşturan bileşenlerden birisi olan yapılar, aynı zamanda bulundukları dönemin toplumsal, siyasi, kültürel ve ekonomik dönemlerine ışık tutmaları sayesinde bir diğer bileşen olan beşeri bileşenlere de ışık tutarlar. Kentler de geçmişlerinin katkısıyla kimlik sahibidirler. Çünkü kentsel kimlik bir kenti diğerlerinden ayıran, o kente özgü olan farklılıklar bütünüdür. Kentlerin sahip olduğu yapılar geçmişten bugüne o kentte yaşayan toplumun anıları ile daha da anlam kazanır ve toplumsal bellekte yer eder. Bu nedenle bu yapıların korunarak gelecek nesillere aktarılması ve sürdürülebilir kimliğin sağlanması gereklidir.

\section{YER, MEKÂN, BELLEK VE YEREL KIMLIIK 3.1. Yer, mekân ve bellek}

1967'de Webber'in fark ettiği gibi yere bağımlı olmayan kentsel alanlar hızla oluşmaktadır. Bir yandan dünyanın küçülmesi, 'yer'lerin birbirine yaklaştırılması, bir yandansa insanın insana ve insanlığa uzaklaşması, yabancılaşması aynı anda söz konusudur. Bu iletişim araçları bize -bugünkü kullanılma biçimleri yüzünden- gerçek yerlerin içeriklerinden kopartılmış görüntülerini sunmaktadırlar. Ando'nun da dediği gibi "yerin ruhunu bugün kurtaracak olan, ne tarihe ne de toprağa dönmektir. Onun yerine toprak ve tarihi uyandırmaktır" (Akcan, 1996; Ciravoğlu, 2006, s.55).

Türkçede, 'yer' kelimesi "Bir şeyin, bir kimsenin kapladığı veya kaplayabileceği boşluk, mahal, mekân" olarak tanımlanır. Başka bir deyişle neredeyse dünya üzerindeki ve gök altındaki her alanı kapsayabilir. Aslında 'yer' konusu ve kelime anlamı çok karmaşıktır. Pratikte, insanların neyin yerine 'yer' kelimesini kullandıklarını ayırt etmek, takip etmek neredeyse imkânsızdır. Fakat şu bir gerçektir ki, 'mekân' ve 'yer' kelimeleri, benzerlik, 
yakınlık ve birlikteliklerine rağmen, farklı anlamlara çağrışım yaparlar (Tuncer, 2010, s.6). 'Mekân (Space)', 'Yer (Place)'den daha soyuttur. Ayrımı tanımlanmamış mekân, daha iyi tanıdıkça ve değer verdikçe 'yer' e dönüşmektedir. Mekânın yere dönüşümü bedenin mekân la ilişkili duygusal bir bağ kurduğu şeklinde de açıklanabilir (Adiloğlu, 2006, s.293-297).

"Mekân, insanı biçimlendiren ve onun tarafından biçimlendirilen toplumsal bir boyuttur" (Harvey, 2003, s.n.y). Buradan çıkan sonuç ise, insan ve mekânın sürekli bir etkileşim içinde olduğudur. İnsan-mekân ilişkileri konusu, yer/mekân ve mekân kimliği ile ilgili çalışmaların önemli bir sorunudur. Mekânlarla ilişkiler kişinin ve kimliğin gelişiminin kaynağı iken, bireyler de kendi özlerini ve mekân la ilişkileri sayesinde sosyal aitliklerini yansıtmaktadırlar. Bu tür ilişkilerde, mekânlar fiziksel çevre ve insan faaliyetleri tarafından meydana getirilmiş gibi görünmektedir. Bireylerin zihinsel ve duygusal süreçleri, oluşturulan çevrede bulunan diğer insanların faaliyetleri tarafından olduğu kadar bireylerin kendilerinin yaptığı eylemler tarafından da etkilenmektedir (Arabulan, 2008, s.4).

Öte yandan, yaşantı, fiziksel formlar olan mekânların daha ötesinde, anlamlı ve deneyimlenmiş olanın içinde geçer. Çünkü mekâna, zayıf ya da güçlü, tekil ya da çoğul, çok çeşitli şekillerde tutunulur. Mekân la kurulan her türlü bağ onun anlamını değiştirir. Bu bağlarla, mekân ile kurulan ilişkisellik çoğalır, deneyim artar. Herhangi olan mekân artık, tanıdık, deneyimlenmiş, anlamlı 'yer'e dönüşür. 'Yer', mekân la ilişki kurmanın ve dünyaya tutunmanın, onda var olmanın yoludur (Tuncer, 2010, s.12). Yerin, zaman içerisinde biriktirdikleri, onun anlamını ve ruhunu oluşturur.

"Mekânın yere dönüşmesi insanın bir mekân ı zaman içinde tanıyışıyla birlikte oluşur... Ne zaman ki mekân üç boyutlu bir yapı, derinlik kazanır o zaman yere dönüşür. Bu derinliğin bir bölümü fizikseldir. Çoğunlukla harekete bağlı duyulara dayanır: renk, doku, ışık, rüzgâr hissi, çevre sesleri... Bu bir anlamda mekânın edebi hissidir." (Ryden, 1995, s.290-292). Bu his, yıllar boyu oluşan deneyimlerin sonucudur. Yeri karakter sahibi yapan; insanın yanında, içinde deneyimlerini barındığı tarihtir, anılardır. Mekân ancak bu şekilde anlamlı hale gelmektedir.

Rossi'ye göre kenti oluşturan mimariler, mekânları üzerinden üretilen sosyal ilişkilerle kent belleğinin bir parçası haline gelmekte, bu ilişkiler ağı kentin tarihi içinde akarak zamanla onu biçimlendirmekte, yeniden üretmektedir. Rossi, kolektif belleği kente içkin ve onunla bir bütün olarak görürken, kentin yaşayan bir organizma gibi canlı bir 'Öz'e sahip olduğunu da iddia etmektedir. Bu öz sayesinde, kenti yaşayan bir organizma gibi 'canlı' tahayyül eden Rossi, dolayısıyla kent ve mimarlığı belleğin öznesi olarak yorumlamıştır. Yerin, zaman içerisinde biriktirdiklerinin, onun anlamını ve ruhunu oluşturduğunu iddia eden bu tür yaklaşımlar, kent ve mimarlıklar üzerinden oluşan kolektif belleğin yanı sıra, kendisinin de bir belleği olduğunu açıklamaktadır. Kente ait bu bellek, 'kentsel bellek' kavramsallaştırmasıyla literatürde yerini almaktadır (Coşkun, 2013, s.20).

Yer ile ilişkisini kurabilen kent, içinde barındırdıklarıyla özgündür. Yerin sahip olduğu özü, atmosferi hissedilir kılan kentler, diğer kentlerden ayrılırlar ki bunun sebebi yere ait kimliğe sahip olmalarıdır.

\subsection{Yerel kimlik}

'Locus Solus', eşsiz yer kavramları, bugün de kentleri, yer ve coğrafya, toprak ve gökyüzü ile ilk örneksel değerleri anlamak için kullanılan önemli kavramlardır. (Erzen, 2015, s.22). Norberg-Schulz, karakteristik mekân özellikleri içeren doğal ve yapılı 
çevrelerde antik Roma kavramı 'genius-logi' nin (yerin ruhu) izini sürmüştür. Öğretisinin merkezine yerleştirdiği kavram, M. Heidegger'in varoluş felsefesinden esinlenen Norberg-Schulz'un erken modernizmin mekânlarını duyusal/ duygusal/ varoluşsal bağlamlarda eleştirmesine olanak sunar (Alangoya, 2015, s.n.y).

Bir yerin kimliğinin insanın kimliğinin gelişmesinde çok önemli bir rolü olduğunu ve insan varlığının bir vakum içinde değil, sürekli ve karşılıklı bir ilişki kurduğu çevrenin bir parçası olarak geliştiğini "Yerde hayat yaşanır" sözleriyle vurgulayan Norberg-Schulz gerçekleşen bir şey için 'yer almak' deyimini kullandığımızdan ve bu deyimin aslında 'yer' kavramının varoluş için temel önemine dikkat çeker. İnsanların Antik dönemde bu kavramı 'genius-logi' terimiyle karşıladıklarını ve her yerin kendine özgü bir karaktere sahip olduğunu ve herhangi bir yerde yerleşip orada yaşamak için ilk önce o yerin ruhuyla anlaşmak gerektiğini söyler. Bu yüzden, yapı yapmanın var olan çevreyi kavramak ve ona saygı duymak anlamına geldiğinden ve yapı yapma işinin insanlara varoluşla ilgili bir temel kazandırdığından bahseder. Norberg-Schulz'a göre "GeniusLogi dondurulamaz ve günün gerekleriyle bağlantılı olarak kavranması gerekir. Yer kavramıyla ilgili böyle dinamik bir tanım, var olan bir çevreye yaratıcı bir adaptasyonun temelini oluşturur". Heidegger'in söylediği gibi: "Ölümlüler yeryüzünü kurtarabildikleri sürece yaşarlar, inşa ettiğimiz her yapı dünyamızın bir bölümünü kurtarmak için bize imkân sağlar" (Norberg-Schulz, 2001, s.42-43).

Yeryüzünü insanoğlunun tüm ihtiyaçlarını karşılayacağı hammaddeleri sunan sonsuz bir kaynak olarak gören Erzen'e göre; doğa, kendi doğamızı besleyen ve iç dünyamızda gizemli dinamiklere neden olan bir krater gibidir. Yeryüzünün bu sonsuz gizemli gücü, hem kendi doğamızın, hem yaşadığımız kentlerin, sanatın ve dolayısıyla mimarinin hammaddesidir. Kentsel gelişimleri, mimarlığın pratiğini ve bireyin mimari mekân yaşantısını anlamak için insanın yeryüzü ile yakın ilişkisini ve bedensel alışverişini incelemek son derece önemlidir. Heidegger "Orada olmak (Dasein), var olmak ile aynı şeydir" der. Varlık ancak bir varlık alanı içinde olasıdır; bu nedenle insanın barınması var olması için nasıl şart ise, yeryüzü de insan için gereklidir ve vazgeçilmesi mümkün değildir. Yeryüzünü yalnızca, insanı uzayda yok olmaktan koruyan bir bağ olarak görmek doğru değildir. Aynı zamanda varlığımızın ilk barınağı olarak görmek gerekir. 'Yer' kavramı insan ve yaşamından ayrı bir olguya işaret etmez; Heidegger, "insan bir konumda, yer başka bir konumda değildir" der. Yaşam, ikamet ve insanın varlığı 'yer' ile birliktedir (Erzen, 2015, s.21).

Yere ait özelliklerin tamamını içinde barındıran yerin ruhu sayesinde her yer, kendi belleğine ve anlamına sahiptir. Bu nedenle, yere ait özellikler özgündür ve o yeri diğerlerinden ayırır ve bu farklılıklar bütünü ise yerel kimliği oluşturur.

\section{4. ÇALIŞMA ALANI}

$\mathrm{Bu}$ makalede, yukarıda sayılan kentsel kimlik ve yerel kimlik özelliklerinin çoğunu barındıran Kocaeli'nin yerel kimliğinin izlerinin sürülebileceği ender yerleşimlerinden biri olan Kapanca Sokak çalışma alanı olarak seçilmiştir. Bu sokak, merkez ilçe olan İzmit'in (Şekil 1.) kentsel sit alanı sınırları içerisindeki Akçakoca mahallesinde (Şekil 2.) yer almaktadır.

Kentin yerel kimliğinin izlerinin sürülebileceği tarihi Kapanca Sokak; Akçakoca Mahallesi'nin güneyinde, Sabri Yalım Caddesi ile Sırrı Paşa Caddesi'ni bağlayan sokak doğu-batı istikametinde konumlanmaktadır (Şekil 3.). Sokak sınırı, manzara, malzeme, oran, doluluk-boşluk, yapılaşmış alanlar gibi geleneksel sokak dokusu karakterini koruyabilmiş önemli bir sokaktır. Dar ve dik bir yokuş üzerindeki sokağın sınırlarını, topoğrafyaya uygun yerleşen binalar ve bahçe duvarları belirlemiştir. Kuzey 
tarafından girişinde restorasyon geçirmiş 19. Yy. geç Osmanlı Dönemi'ne ait bir sarnıç (Fotoğraf 1) ile biraz aşağısında 1783 tarihli Kapanca Sokak Çeşmesi (Zeliha Kadın Çeşmesi) (Fotoğraf 2) yer alırken, güney tarafında bugün "Rehberlik ve Araştırma Merkezi Müdürlüğü” olarak kullanılan tarihi Ermeni Protestan Kilisesi (Fotoğraf 3) mevcuttur.

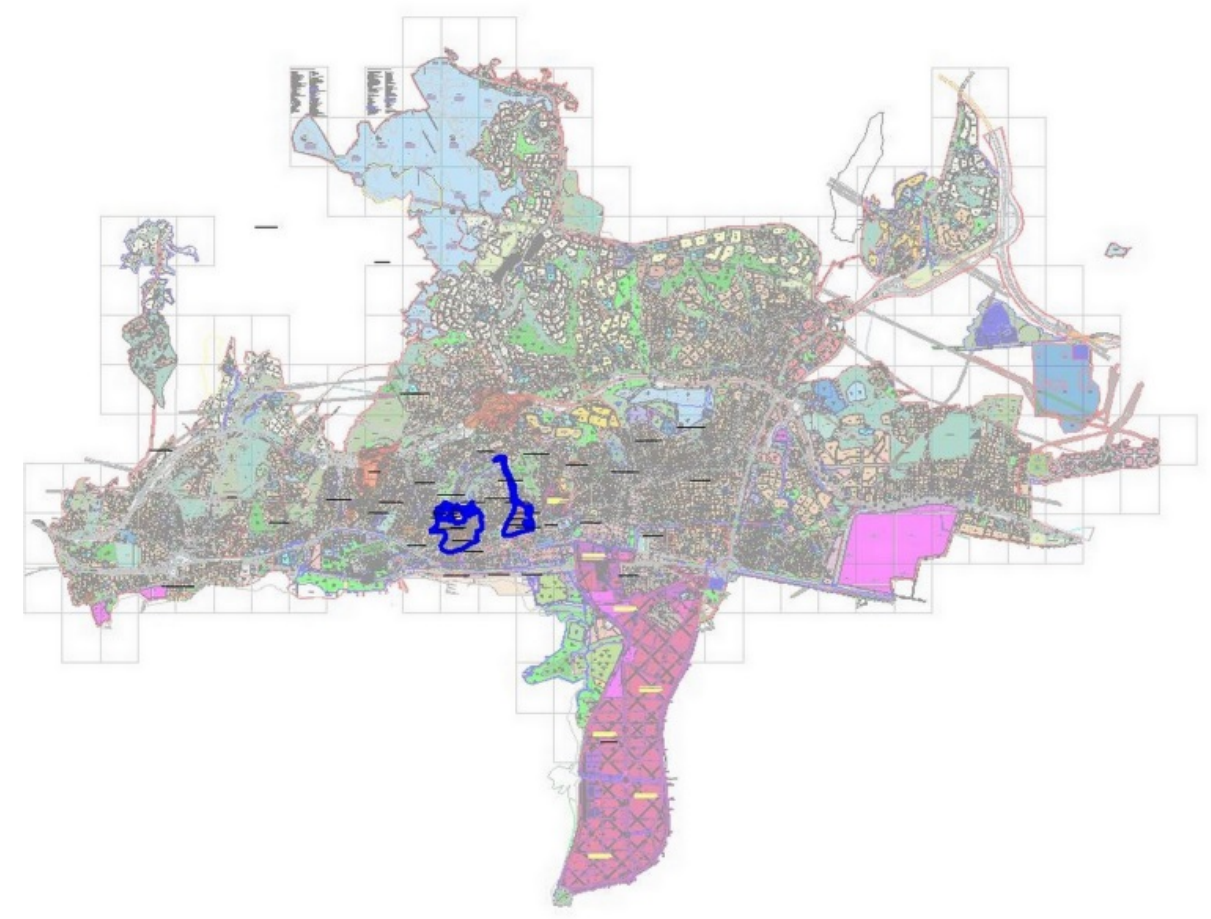

Şekil 1. Kocaeli'nin Merkez İlçesi İzmit (İzmit Belediyesi İmar ve Şehircilik Müdürlüğü Arşivi)

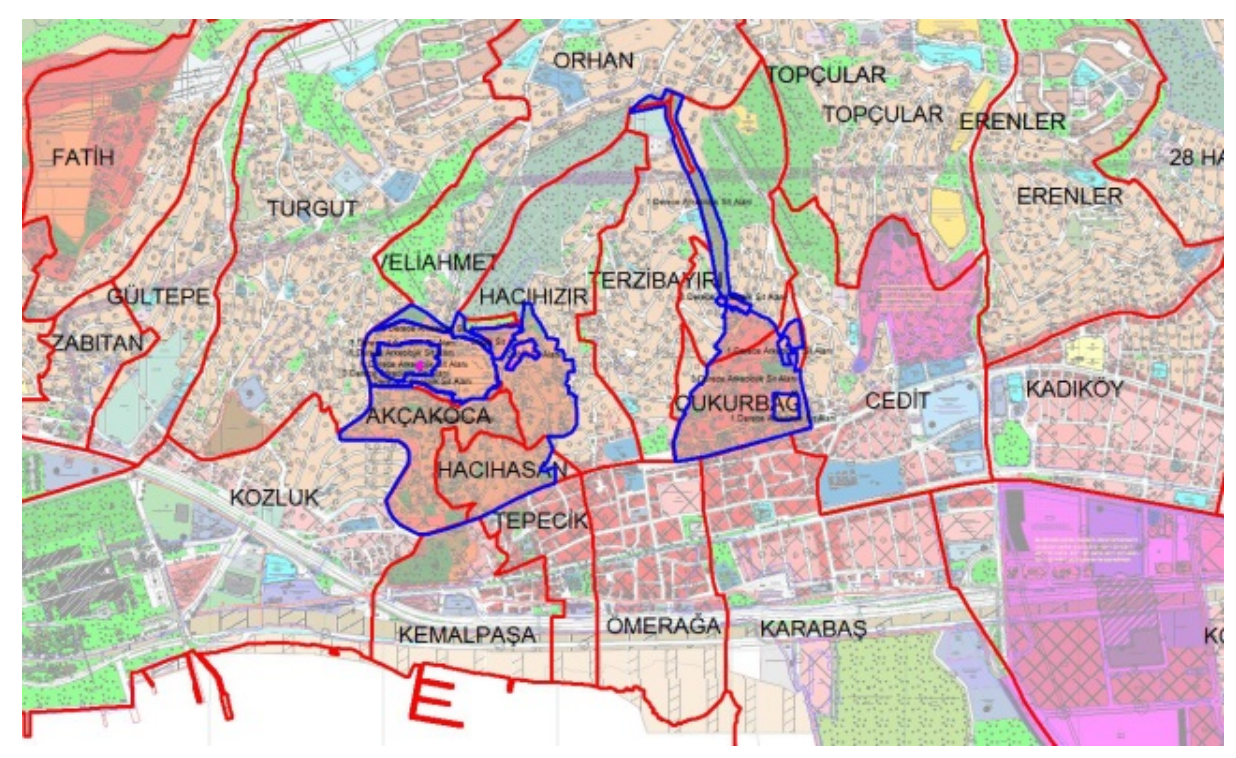

Şekil 2. Akçakoca Mahallesinin İzmit'teki Yeri (İzmit Belediyesi İmar ve Şehircilik Müdürlüğü Arşivi) 


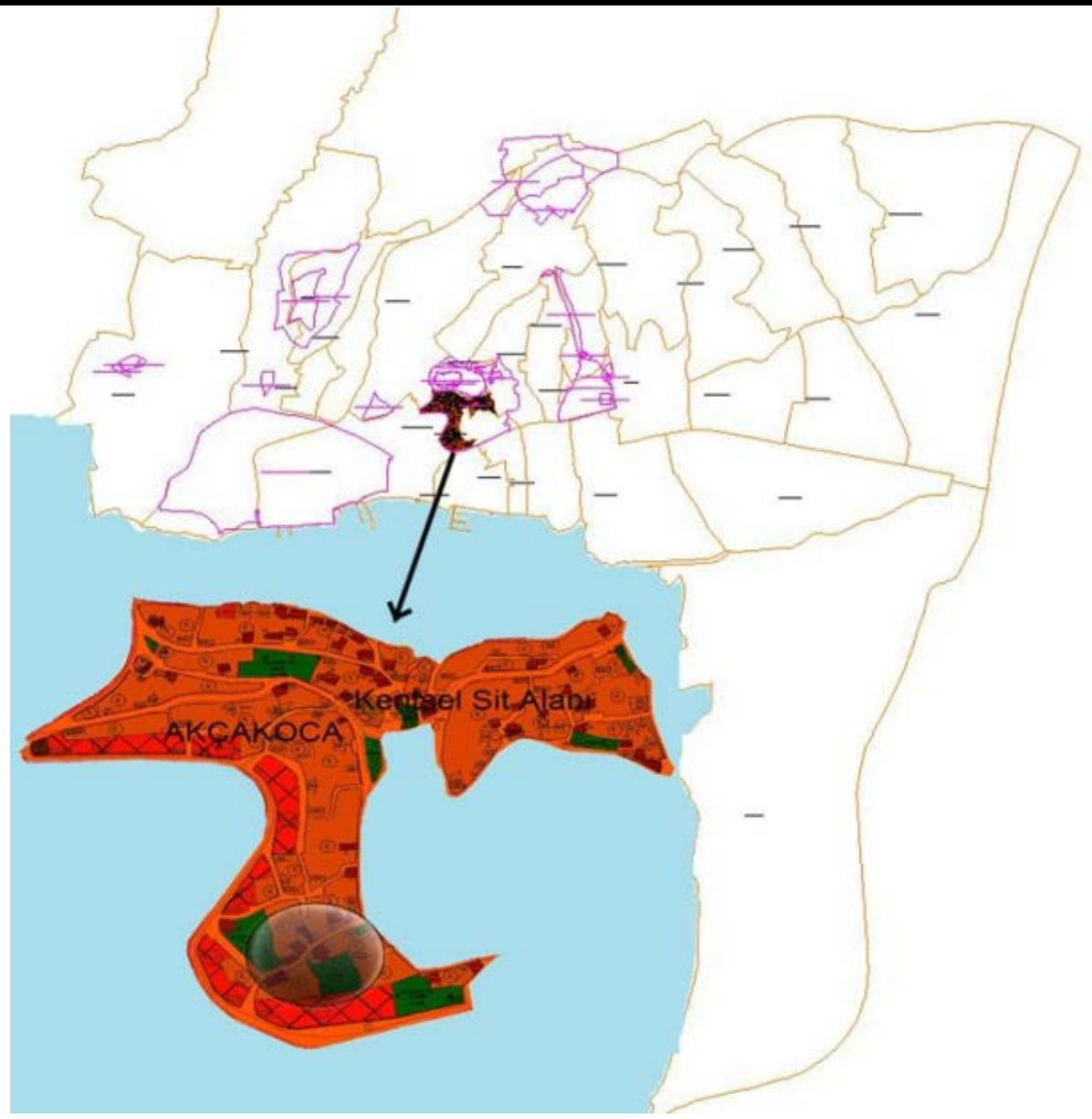

Şekil 3. Kocaeli Kentsel Sit Alanı, Kapanca Sokağın Akçakoca Mahallesi İçindeki Yeri ve İncelenen Tescilli Konutlar (İzmit Belediyesi İmar ve Şehircilik Müdürlüğü Arşivi).

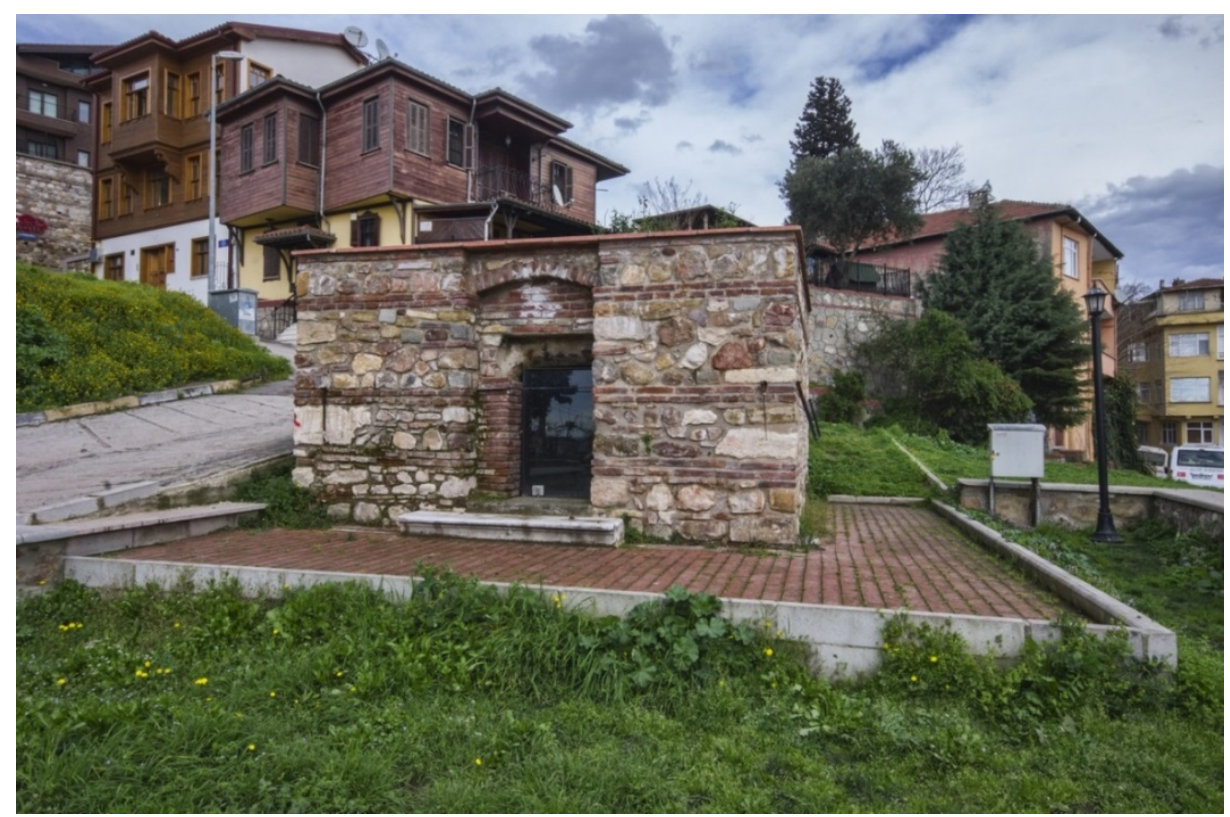

Fotoğraf 1. 19. YY. Geç Osmanlı Dönemi'ne Ait Sarnıç

(Fot. 1: Sonay Ayyıldız, 2016) 


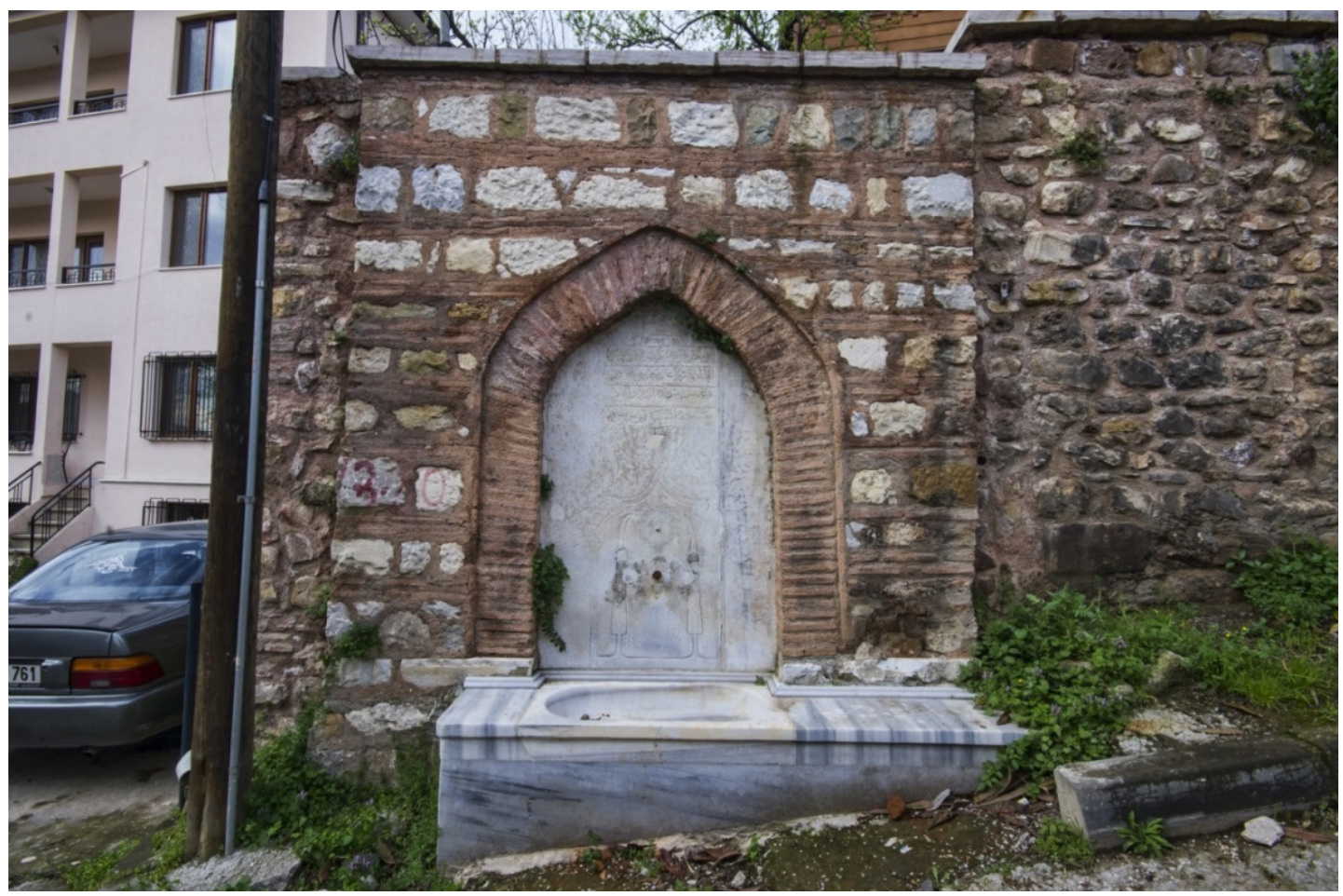

Fotoğraf 2. 1783 Tarihli Kapanca Sokak Çeşmesi

(Fot. 2: Sonay Ayyıldız, 2016)

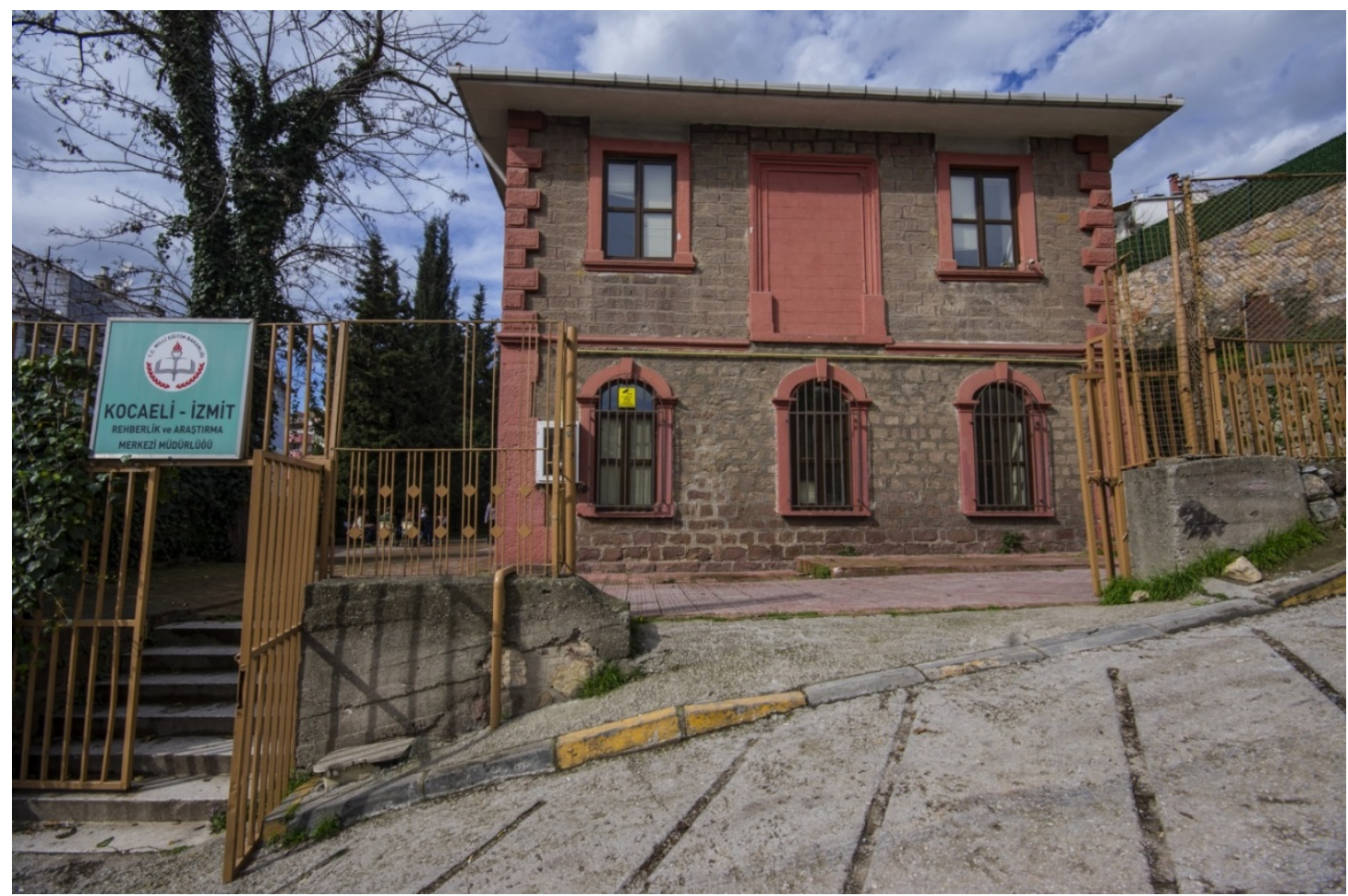

Fotoğraf 3. Bugün "Rehberlik ve Araştırma Merkezi Müdürlüğü" Olarak Kullanılan Tarihi Ermeni Protestan Kilisesi (Fot. 3: Sonay Ayyıldız, 2016) 


\section{5. ÇALIŞMANIN AMACI VE YÖNTEMI}

Yüzyılı aşkın tarihi geçmişe sahip olan ve özgünlüğünü günümüzde de koruyan Kapanca sokağının taşıdığı değerlerin geleceğe iletilebilmesi, kimliğinin ortaya çıkarılması ve kültürel sürekliliğin sağlanabilmesi için kayıt altına alınması gerekliliği düşünülmektedir.

Çalışmada literatür araştırması ve alan çalışması (fotoğraflama, haritalama v.b.) yapılmış ve Kocaeli'nin tarihi kimliğinde önemli bir yer teşkil eden Kapanca Sokağının kimliği, kentsel kimlik bileşenleri açısından ele alınarak ortaya konulmuştur. Çalışma dört aşamadan oluşmaktadır: Sokak, birinci aşamada doğal çevre bileşenleri, ikinci aşamada yapay çevre bileşenleri, üçüncü aşamada tarihsel süreç ve dördüncü aşamada ise sosyo-kültürel değişim açısından analiz edilmiştir.

\subsection{Doğal çevre bileşenleri açısından analiz}

Heidegger'in "Bir bina yerin ve oturanların özelliklerine göre inşa edilir, bulunduğu fiziksel ve beşeri topografya ile şekillenir" söylemi mimarlık ve doğa arasındaki ilişkinin gerçekliği açısından son derece önemlidir (Sharr, 2013, s.10).

Kocaeli coğrafi konumu, doğu-batı arasında geçişi sağlayan köprü özelliği, deniz ve kara ulaşımının verdiği imkân lar nedenleri ile ilkçağlardan beri önemli bir şehir olmuştur (İzmit Analitik Etüdleri, 1970, s.8; Erdoğan, Ayyıldız ve Özbayraktar, 2011, s.13). Kapanca sokak ise, bugün gizli kalmış İzmit Kentsel Sit Alanı'nın kent merkezinden giriş kapısı niteliğinde ve özgün dokusunu büyük ölçüde korumuş önemli tarihi bir sokaktır. Geçmişte de ana caddeden Çarşı-i Müslim mahallesinde bulunan çarşıya geçiş yolu üzerinde bulunmaktadır. Bulunduğu konum sokağın adını almasına da neden olmuştur. Kapanca (Kapancı) adını isminden de anlaşılacağı üzere Kapan işi yapan kişilerin yaşadığı yeri tariflemektedir. Ayrıca adını, 1900'lerin başında İzmit kent merkezinde 'Kapanönü' adıyla bilinen çarşıya yakınlığından ötürü aldığı düşünülmektedir. Osmanlıca-Türkçe sözlüğe göre ise; Kapan: Pazara satılmak üzere gelen yiyecek maddelerinin tartıldığı resmi kantar; bu kantarın bulunduğu yer, Kapancı: Yiyecek maddelerinin tartıldığı resmi kantarın başında bulunan görevlidir (Tuğlacı, 1972, s.1377-1379).

Çalışma alanının başlangıcı olan Rehberlik ve Araştırma Merkezi Müdürlüğü'nün Kapanca Sokak üzerindeki parsel sınırının alt kotu ile sokak sonu olan Sırrı Paşa caddesi ile kesişim noktası kotu arasındaki fark alınarak hesaplandığında \%19.63 derecelik bir eğim olduğu tespit edilmiştir. Sokakta yer alan konutlar incelendiğinde ise toprağa oturan bodrum veya zemin katların yapım sisteminin eğimden kaynaklı olarak yığma taş duvar olduğu görülmektedir.

Kocaeli ikliminin, Akdeniz iklimi ile Karadeniz İklimi arasında bir geçiş oluşturduğu söylenebilir. İzmit'te yazlar sıcak ve az yağışı, kışlar yağışlı, zaman zaman karlı ve soğuk geçer (Kocaeli İl Yıllığı, 2001, s.15-20; Bölgesel Göstergeler, s.IX-X). Bu sebeple konutlar kırma çatılı ve bakıları manzara (İzmit Körfezi) ve güneye yöneliktir. Konutlar bahçeli olup, bahçelerinde çeşitli meyve ağaçları bulunmaktadır (Fotoğraf 4). Bu özellikleri ile bir çok şaire bile ilham kaynağı olmuştur. 


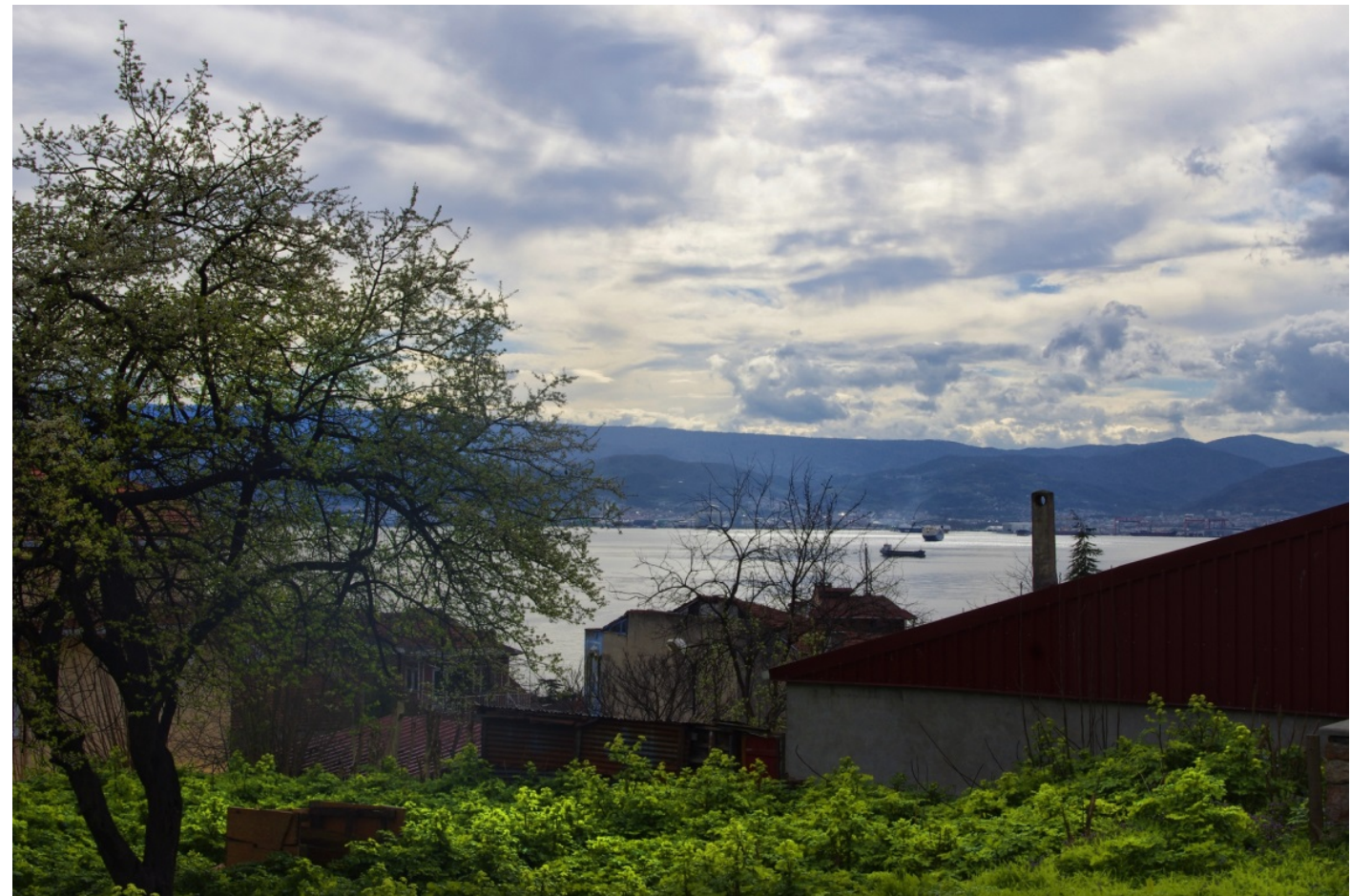

Fotoğraf 4. Kapanca Sokaktan Bir İzmit Körfezi Manzarası

(Fot. 4: Sonay Ayyıldız, 2016)

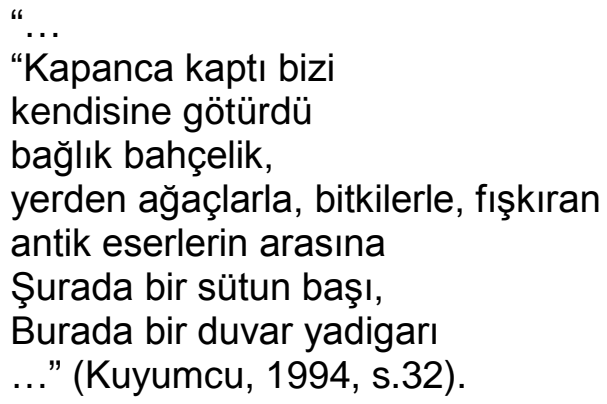

Yukarıda bahsedilen özellikleri göz önüne alındığında; Kapanca Sokak'ta doğal çevre verilerinin etkili olarak kullanıldığı açıktır.

\subsection{Yapay çevre bileşenleri açısından analiz}

Tarihi kent merkezinin içinde yer alan Kapanca sokak, kimlik anlamında geçmişten gelen çok önemli değerlere sahip olmasına rağmen, yakın zamanda çevresi çok katlı sıradan apartmanlarla sarılmış ve algılanamaz bir duruma gelmiştir (Fotoğraf 5). Bu nedenle bu bölümde Kapanca Sokak Gestalt Algı Kuramı çerçevesinde ele alınıp incelenmiştir.

Gestalt psikolojisi ile ortaya konulan algısal gruplama ilkelerine göre, çevremizdeki objeler organize edilmiş bütünler şeklinde algılanır. Bu organizasyonun bazı ilkelerini Lang (1987) Yakınlık, Benzerlik, Devamlılık ve Kapalııı olarak sınıflamıştır (Aytem, 2005, s.18). 


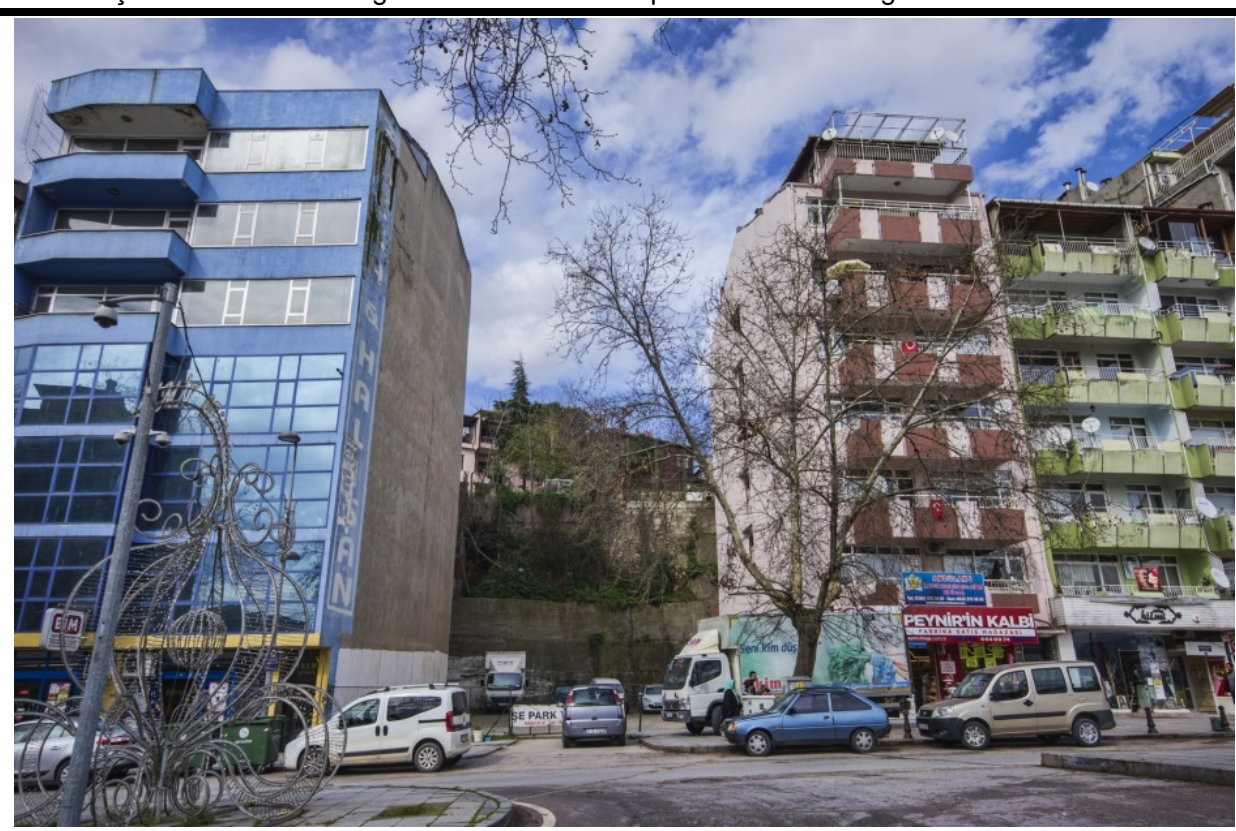

Fotoğraf 5. Çok Katlı Apartmanlar Arkasında Algılanamayan Kapanca Sokak (Fot. 5: Sonay Ayyıldız, 2016)

Sokaktaki konutların birbirlerine olan yakınlıkları, daha kesin sınırların oluşumunu sağlamakta ve gruplaşma eğilimi göstermektedir (Şekil 4).

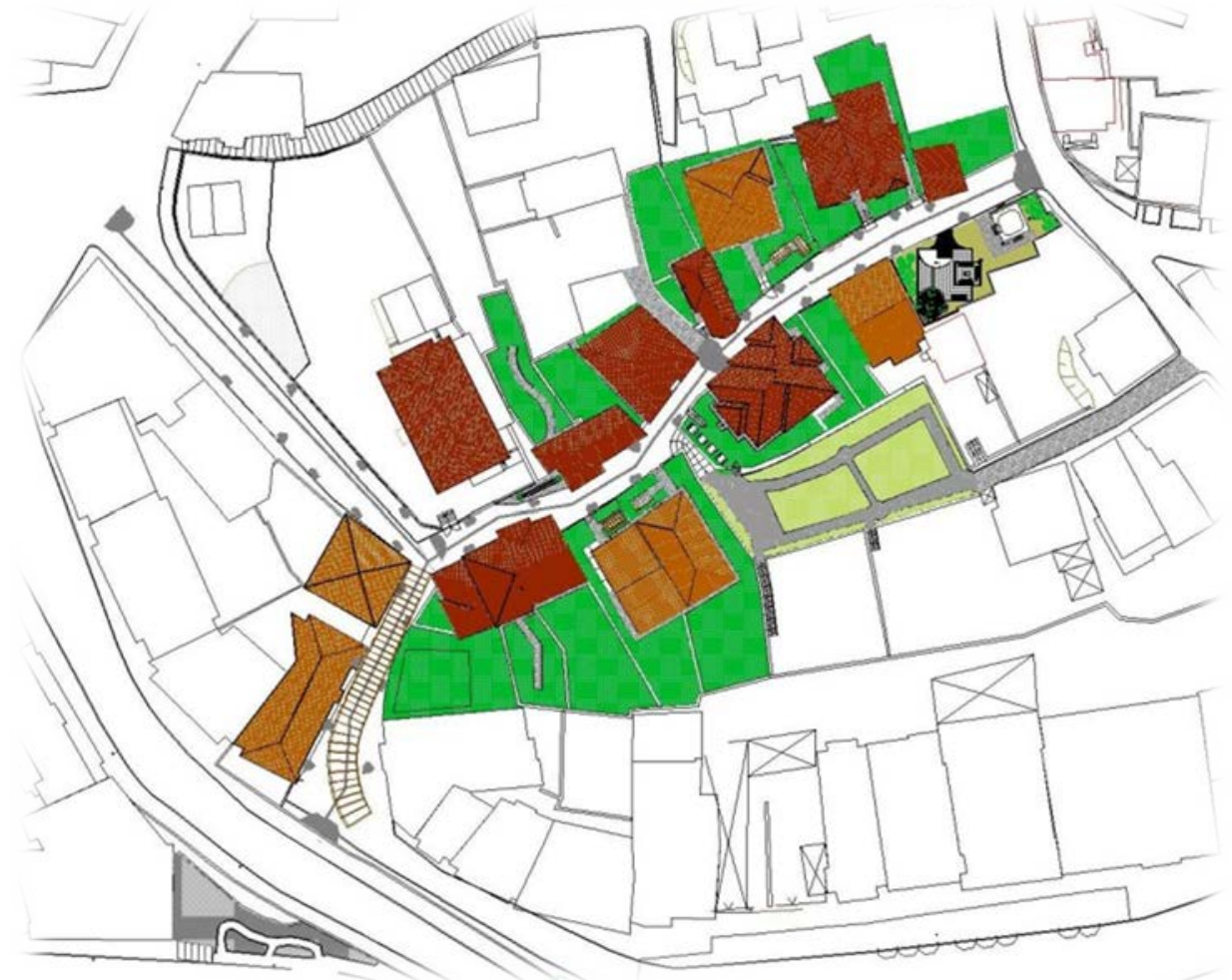

Sekil 4. Konutların Birbirlerine Olan Yakınlığı (Şekil 4: İzmit Belediyesi Etüt Proje Müdürlüğü Arşivi) 
Konutların cephe özelliklerinden doluluk-boşluk oranları, girinti-çıkıntıları (cumbaları) ve malzemelerindeki benzerliklerinden dolayı sokak bir bütün olarak algılanmaktadır (Şekil 5).

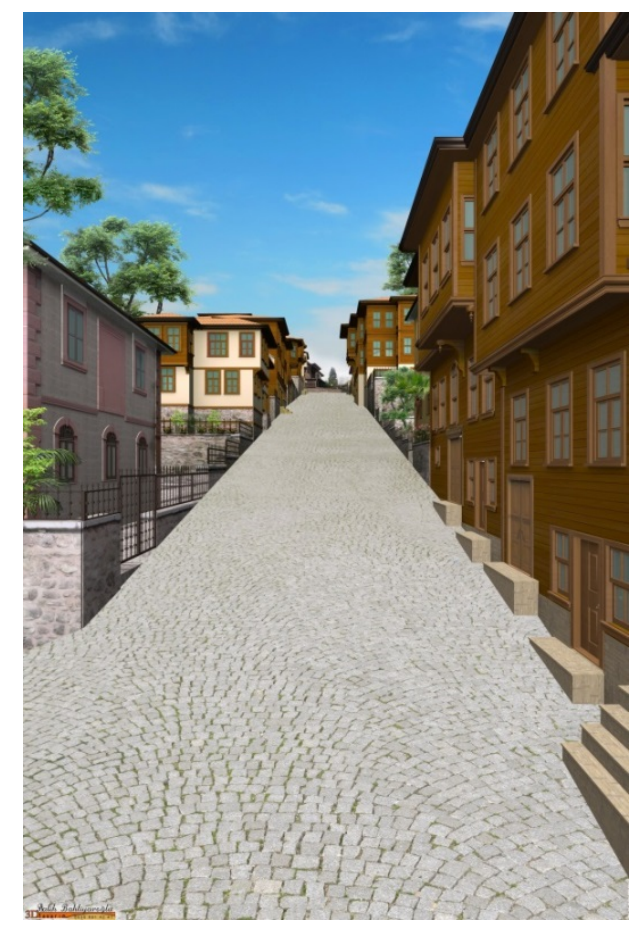

Şekil 5. Konutların Birbirlerine Olan Benzerliği-Sokaktaki Restorasyon ve Rekonstrüksiyon Çalışmaları Tamamlandığında Oluşacak Sokak Canlandırması

(Şekil 5: İzmit Belediyesi Etüt Proje Müdürlüğü Arşivi)

Sokakta bulunan 10 tescilli konutun 8'i sokağa dayalıdır. Ayrıca 5 ve 6 envanter nolu konutlar ile 10, 11 ve 12 envanter nolu konutlar ise hem sokağa dayalı hem de bitişik nizamlıdır. Binaların ardışık düzende ve aynı istikamette devam etmesi, bir bütün oluşturarak birlikte algılanmalarına sebep olmaktadır (Şekil 6, 7, 8).

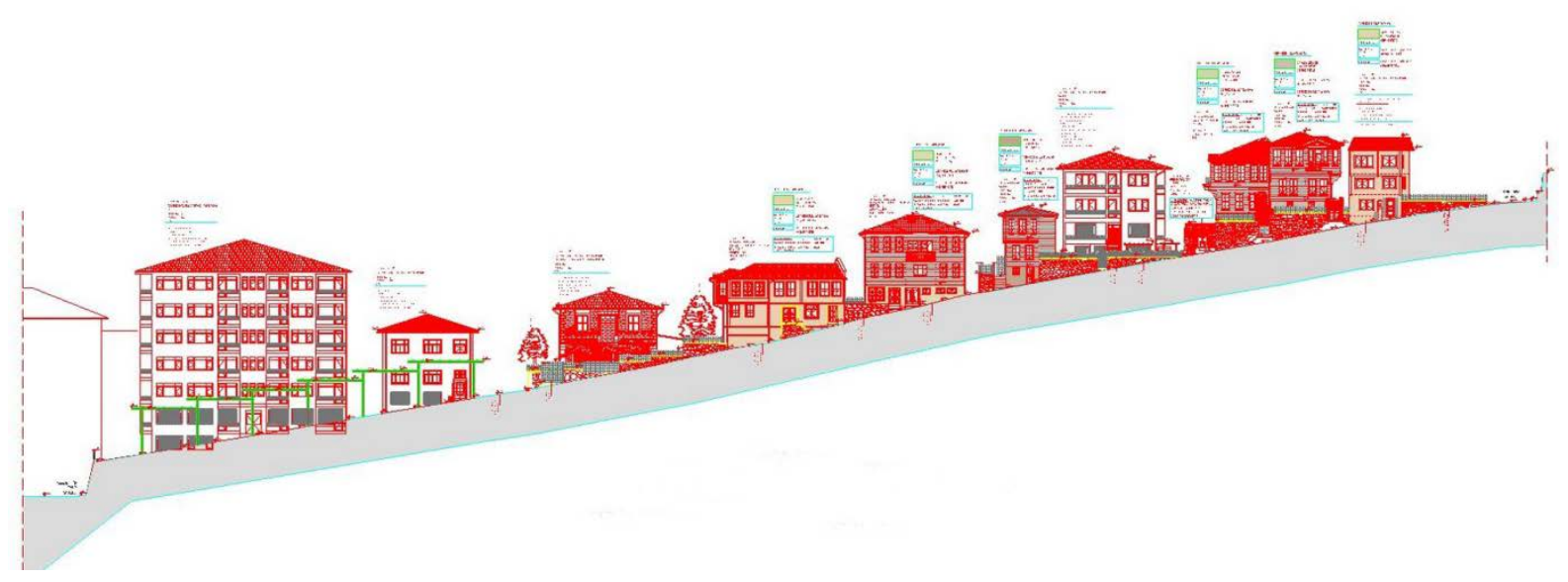

Şekil 6. Konutların Devamlılı̆ı̆-Sokağın Kuzey Silueti (Şekil 6: İzmit Belediyesi Etüt Proje Müdürlüğü Arşivi) 


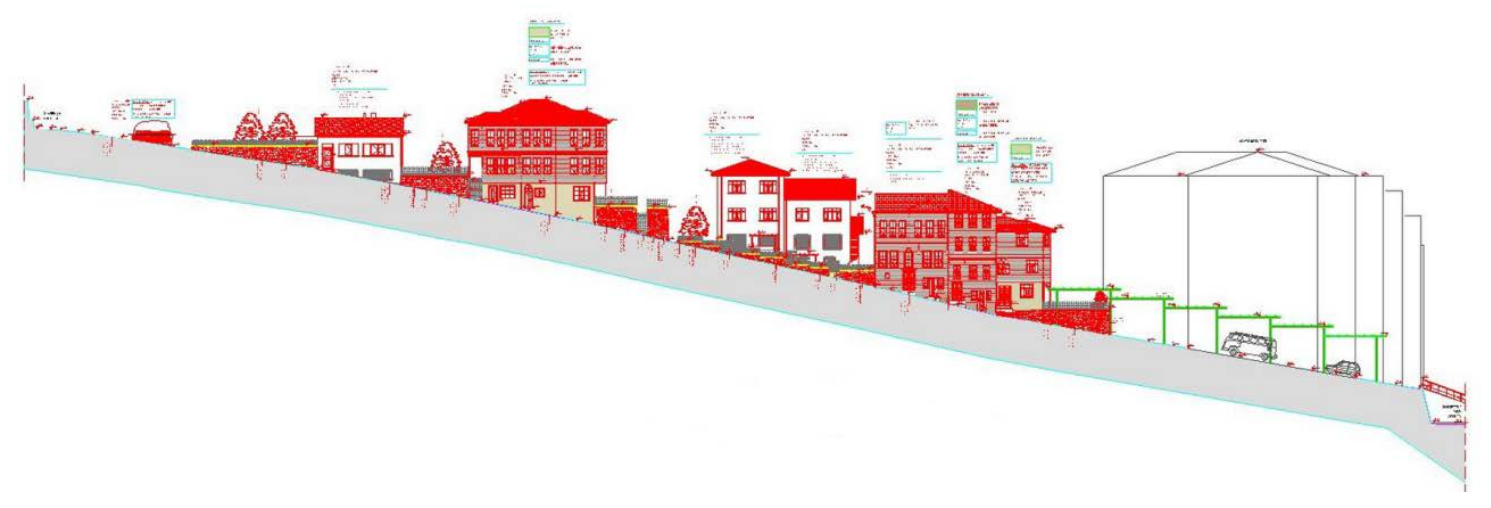

Şekil 7. Konutların Devamlılı̆ı-Sokağın Güney Silueti (Şekil 7: İzmit Belediyesi Etüt Proje Müdürlüğü Arşivi)

Şekil 8'de görüldüğü gibi sokak boyunca yer alan parsellerin sürekliliği, konutların ve bahçe duvarlarının bir sınır oluşturması sebepleriyle yerleşim kapanarak tam bir sokak olarak algılanmaktadır.

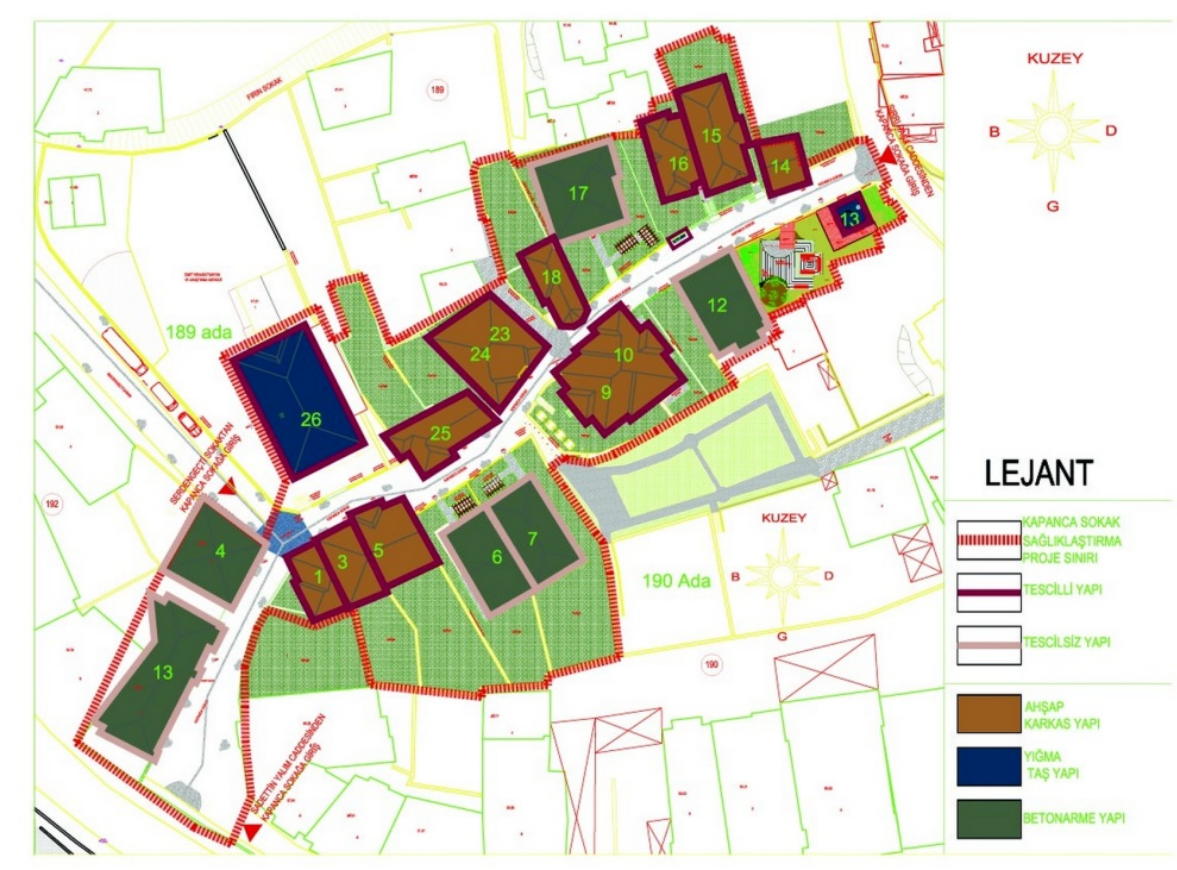

Şekil 8. Konutların ve Sokağın Kapalılı̆ı

(Şekil 8: İzmit Belediyesi Etüt Proje Müdürlüğü Arşivi)

\subsection{Tarihsel süreç açısından analiz}

Akçakoca Mahallesinde son yüz yıldır adı ve dokusu değişmeyen iki sokaktan biri olan Kapanca Sokak 1914'de Ermeni Mahallesi'nin bir parçasıdır (Şekil 9). 1927'de mahallenin ismi Kozluk olarak değişmiştir. Günümüzde Akçakoca Mahallesi sınırları içinde yer almaktadır. 


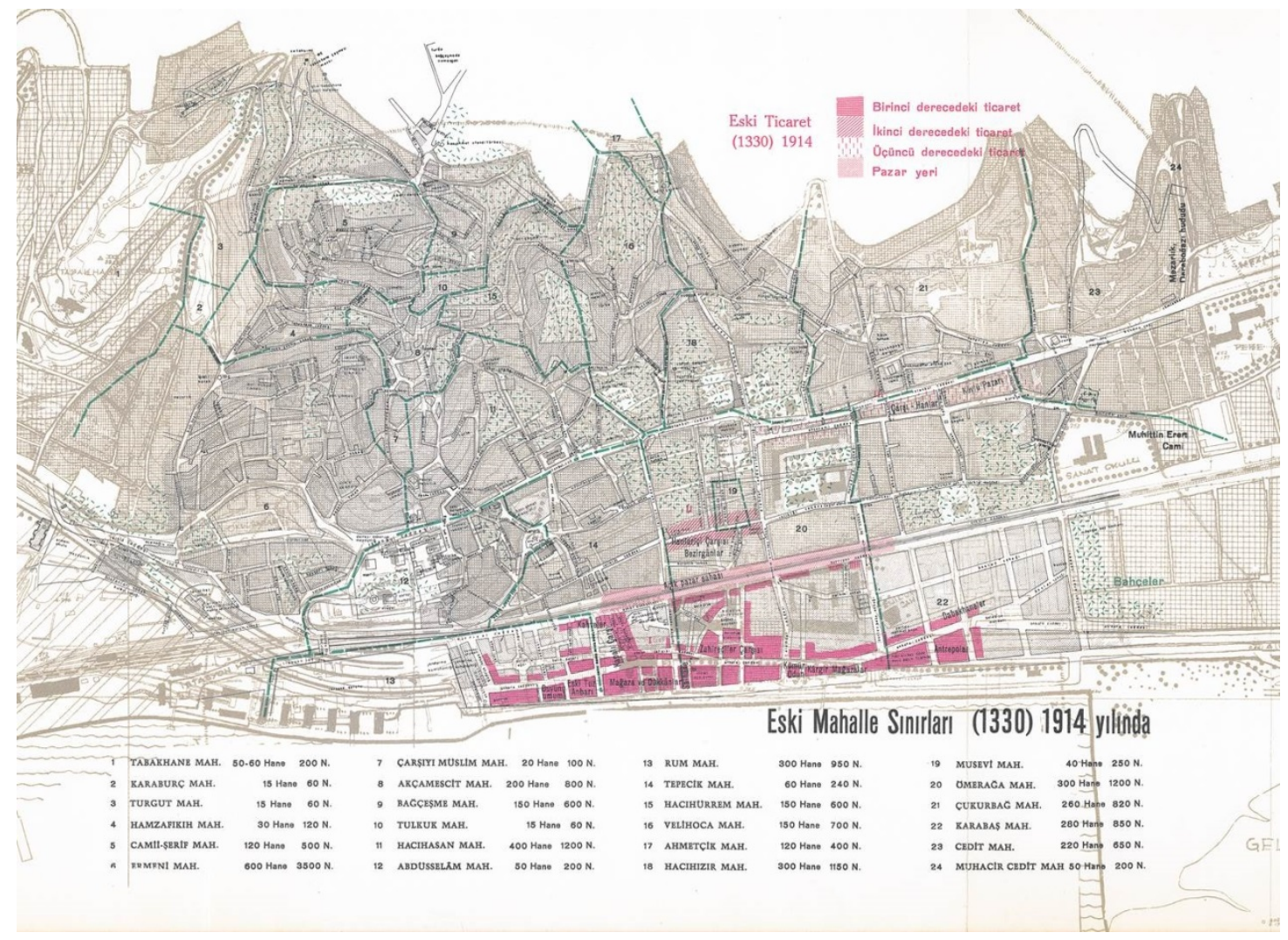

Şekil 9. İzmit'in 1914 Yılındaki Mahalleleri

(Şekil 9: İmit Analitik Etüdleri, 1970, s.11.)

1987'de alınan kararla Kapanca Sokak korunacak sokaklardan biri olarak belirlenmiştir. İlk revitalizasyon çalışmaları, 'İzmit Evlerini Koruma ve Yaşatma Projesi (IZEYAP)' ile başlamış, 1994 'te 25 resmi kuruluş ve sivil toplum örgütünün katıııı ile imzalanan 'Sırrı Paşa Sözleşmesi'nin ardından IZEYAP resmiyet kazanmıştır (Şen, 1996, s.24). Projenin amacı İzmit kentinin kimlik sorununa çözüm getirmek, kentlinin yaşadığı ortama duyarlıı̆̆ını sağlamak, sorunları belirginleştirip kente sahip çıkmasına öncülük etmektir (IZEYAP Bülteni, 1995, s.16-17). 1994'de Kapanca Sokağı'nı da içine alan 'Koruma Amaçlı İmar Planı' yapılmıştır. 2003 yılındaki koruma amaçlı imar planında 'Kentsel Sit Alanı' içinde yer almaktadır. Sokağın 2003 yılındaki durumu Fotoğraf 6'da görülebilmektedir.

Özellikle Mimarlar Odası İstanbul Büyükkent şubesine bağlı çalışan Galata grubu IZEYAP projesinin önemli bir bileşeni olmuştur. Galata grubu, Kapanca Sokağı'nın tümünde rölöve ve restorasyon projesi yapmış, kentsel tasarım projesi geliştirmiştir. Bu çalışmalardan sonra IZEYAP ile 1995-1996 yıllarında sokakta bulunan 12 tescilli yapıdan 10'unun çatısı, 7'sinin cephe onarımında birinci ve ikinci katlarının ahşap kaplamaları yenilenmiş, zemin katlarındaki taş duvarlarda herhangi bir onarım yapılmamıştır (Ayyıldız ve Özbayraktar, 2005, s.34-37). Saraybahçe Belediyesi, IZEYAP projesi kapsamında tescil levhalama çalışmalarını yapmıştır. Yapıların tescil numaraları Şekil 13'de görüldüğü gibidir. 


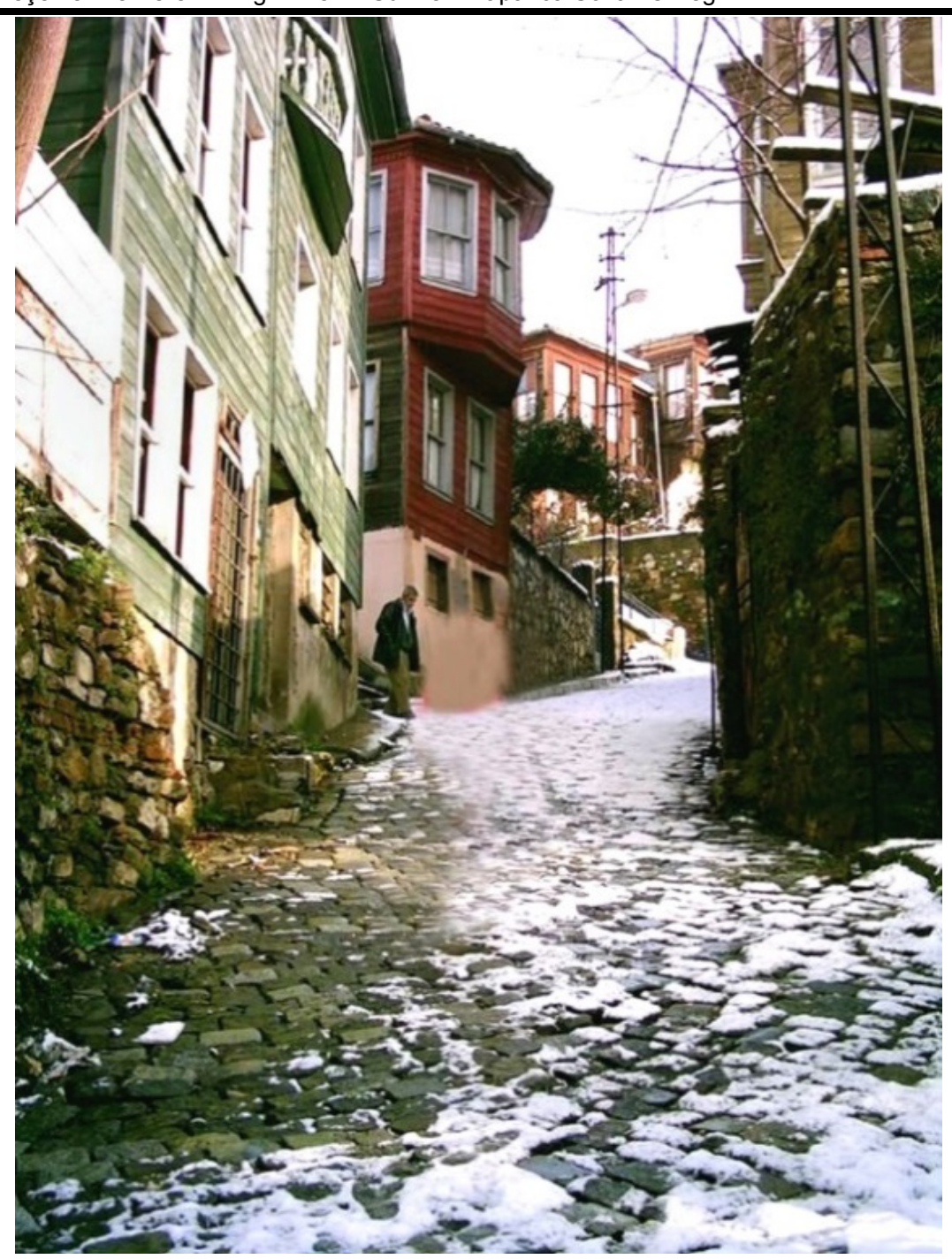

Fotoğraf 6. Kapanca Sokağın 2003 Yılındaki Durumu (Fot. 6: Sonay Ayyıldız, 2003)

2005 yılında Kocaeli Büyükşehir Belediyesi, Mimarlar Odası, Valilik, Saraybahçe Belediyesi, Kültür Turizm Müdürlüğü ortaklaşa 2. Sırrı Paşa Sözleşmesi'ni imzalamıştır. Sözleşme ile İzmit'in önemli valilerinden Sırrı Paşa'nın görkemli konağının onarımının önü açılmış, Kapanca Sokak Evleri için de yeniden koruma ve yaşatma kararı" alınmıştır (Akcan, 2006, s. 28-29).

Bugün İzmit Belediyesi tarafından başlatılan Tarih Koridoru projesinin güzergahı üzerinde olan sokakta restorasyon ve rekonstrüksiyon çalışmaları halen devam etmektedir (Fotoğraf 7, 8). 

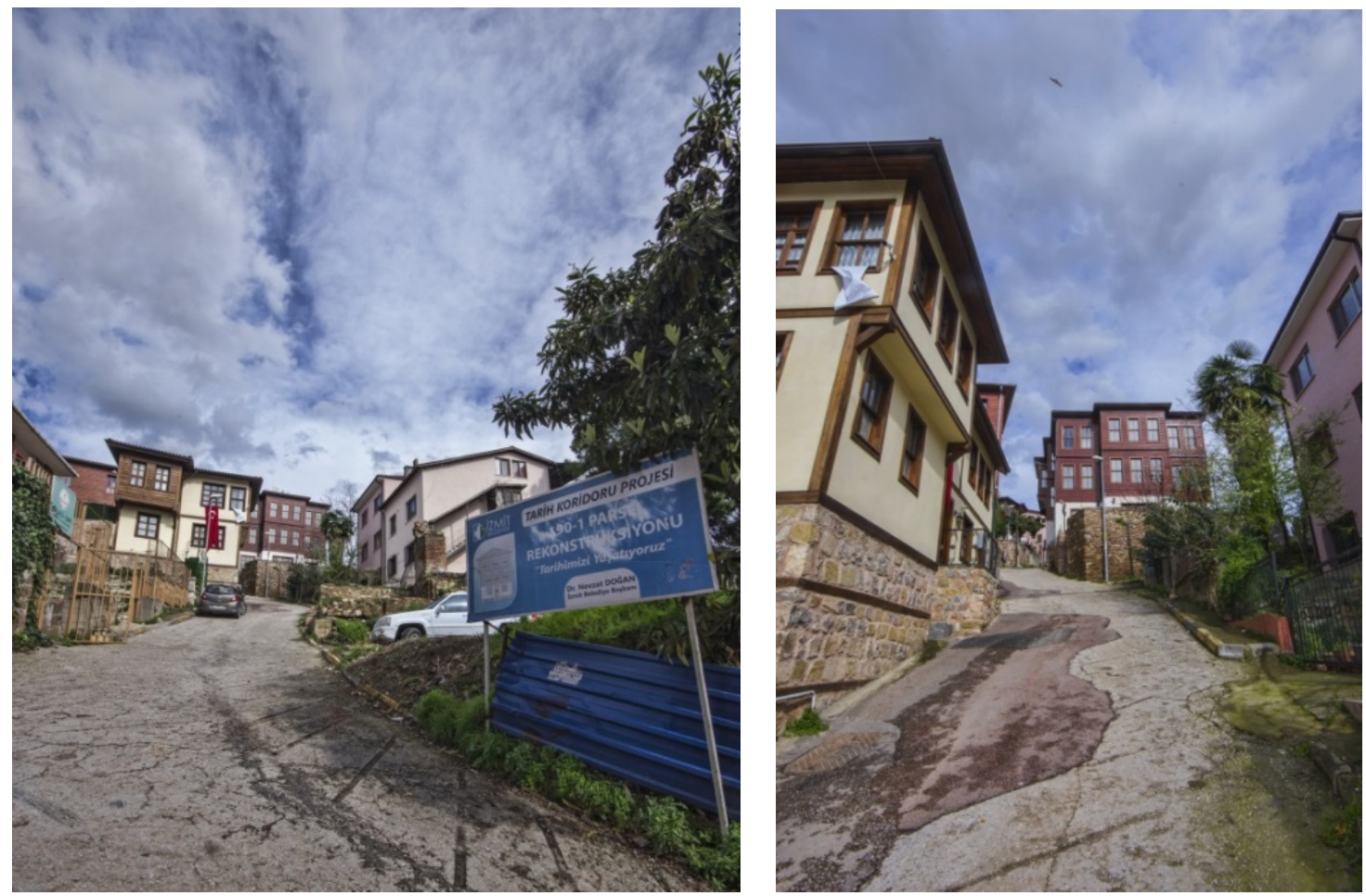

Fotoğraf 7, 8. Kapanca Sokakta Restorasyon ve Rekonstrüksiyon Çalışmaları (Fot. 7,8: Sonay Ayyıldız, 2016)

19. Yüzyıl sonu ve 20. Yüzyıl başlarına ait geleneksel tescilli 12 konutun bulunduğu sokakta yakın zamanda ikişer konutun parsel birleştirme işlemi yapıldığından; bugün kuzey yönünde 6 , güney yönünde 4 olmak üzere toplam 10 adet tescilli konut mevcuttur. Bunlardan 7 tanesi İmit Belediyesi, 3 tanesi ise İzmit Sanayi Odası tarafından istimlak edilerek koruma çalışmaları ile bir kısmı yeniden işlevlendirilmiştir (Tablo 1).

Üç ayrı dönemde yapılmış olan ve 100 yıllık bir periyodu kapsayan zaman içindeki planlar (Şekil 11, 12, 13) incelendiğinde, sokağın morfolojik yapısının; parselasyon durumunun; sokak başlangıç ve bitiş noktası arasındaki kot farkının değişmediği açıkça görülmektedir. 


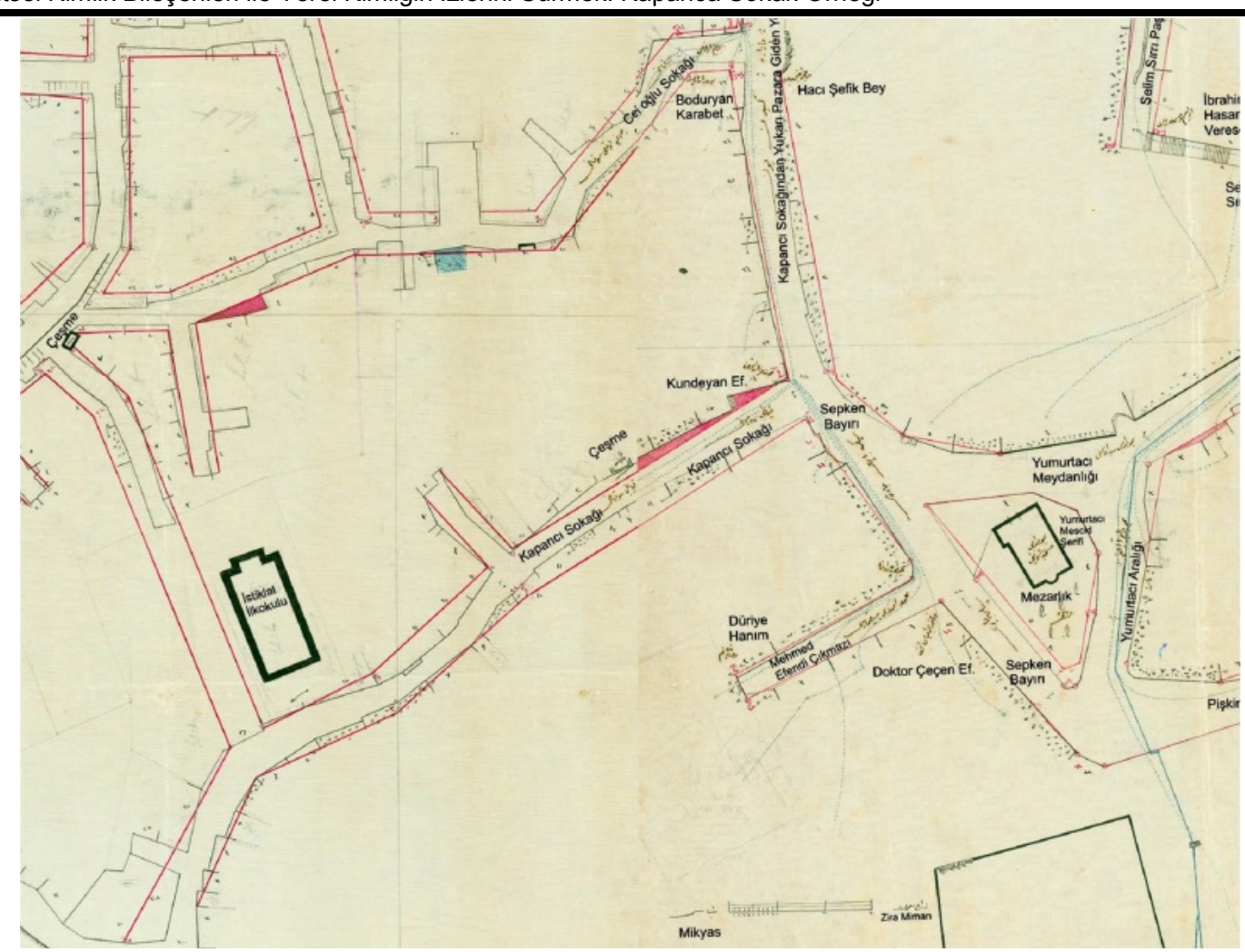

Şekil 11. Kapanca Sokak ve Yakın Çevresi 1925 Yılı İstikamet Planı

(Şekil 11: İzmit Belediyesi İmar ve Şehircilik Müdürlüğü Arşivi)

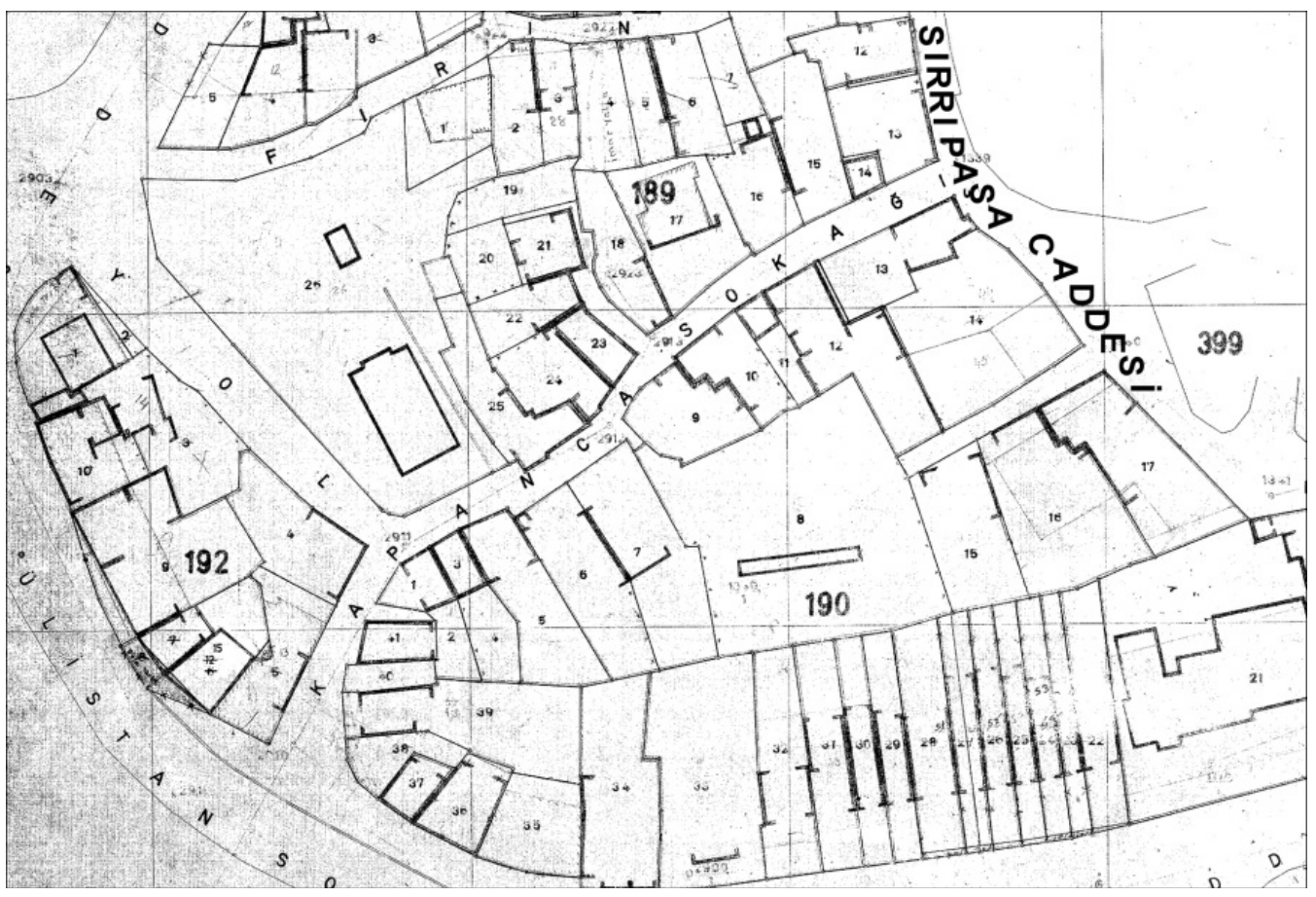

Şekil 12. Kapanca Sokak ve Yakın Çevresi 1965 Yılı Halihazır Durum Paftası (Şekil 12: İzmit Belediyesi Emlak ve İstimlak Müdürlüğü Arşivi) 


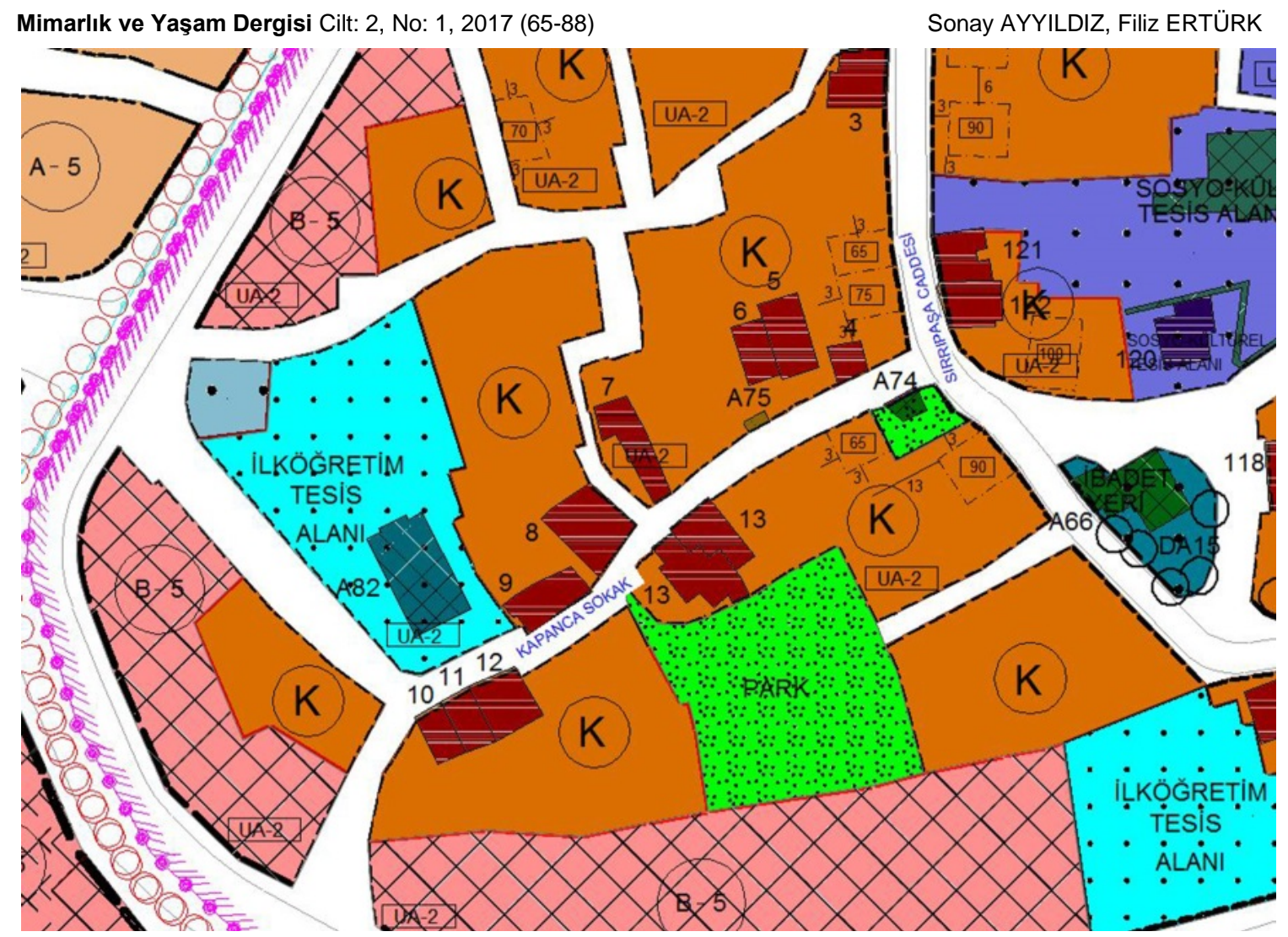

Şekil 13. Kapanca Sokak ve Yakın Çevresi Güncel Koruma Amaçlı İmar Planı (Şekil 13: İzmit Belediyesi İmar ve Şehircilik Müdürlüğü Arşivi)

\subsection{Sosyo-kültürel değişim açısından analiz}

Tarihsel, dinsel ve sosyal geçmişleriyle ön plana çıkan kentler, yasam alanlarında üretmiş oldukları kültürel birikimlerle kendilerine özgü kimlikler oluşturmaktadırlar.

Neill'e (1997) göre; kentte bir yapı veya yapı grubu ortaya çıktığı dönemin yaşantısına tanıklık etmiş hatta doğrudan katılmışsa ve dönemin mimarisini ve kültürünü yansıtıyorsa, kentli için bir anlamı bulunur. Bu anlam, sadece geçmişin hayaline saygıyı içeren nostaljik bir tutum olmayıp, aynı zamanda içinde bulunulan zaman dilimindeki kolektif deneyimi de kapsamaktadır (Birol, 2007, s.46-54).

Yaşlıca, Şenlier, Çalışır ve Hovardaoğlu'na (2002) göre; tarihi dokularımızdaki sokakları ilginç yapan, ayrıcalıklı kılan olgu, sokakları tanımlayan yapılar ile bu yapıların kullanıcıları arasında oluşan diyalektiktir. Sokakların oluşmasına neden olan bu diyalektikte ortaya çıkacak bozulmaların derecesine bağlı olarak, sokaklarda da kimliğin yitirilmesini ortaya çıkartacak değişimler olmaktadır (Özalp, 2008, s.32). Nitekim 2009 yılına kadar konutların çoğunlukta olduğu Kapanca sokaktaki binalar restorasyon ve rekonstrüksiyon çalışmaları ile işlev değişikliğine uğramış; kullanıcılarının değişmesiyle birlikte sokakta sosyo-kültürel bir değişim de yaşanmaktadır. Bu da sokağın özgün kimliğini yitirmesine sebep olmuştur (Tablo 1, 2). 
Kentsel Kimlik Bileşenleri ile Yerel Kimliğin İzlerini Sürmek: Kapanca Sokak Örneği

Tablo 1. Tescilli Konutlar İle İlgili Kullanım Kararları Değişikliği

\begin{tabular}{|c|c|c|}
\hline $\begin{array}{l}\text { BINA } \\
\text { ENVANTER NO }\end{array}$ & ÍLK KULLANIM & GÜNCEL KULLANIM \\
\hline 4 & KONUT & KONUT \\
\hline 5 & KONUT & KONUT \\
\hline 6 & KONUT & MUSTAFA KURT GÜZEL SANATLAR GALERISI \\
\hline 7 & KONUT & $\begin{array}{l}\text { SOSYO-KÜLTÜREL AMAÇLI KONAK } \\
\text { (PROJE AŞAMASINDA) }\end{array}$ \\
\hline 8 & KONUT & $\begin{array}{l}\text { KOCAELİ İMAM HATiP LISELERI MEZUNLARI } \\
\text { DERNEĞi }\end{array}$ \\
\hline 9 & KONUT & KOCAELI GAZETECILER CEMIYETI \\
\hline 10 & KONUT & $\begin{array}{l}\text { OTEL } \\
\text { (PROJE AŞAMASINDA) }\end{array}$ \\
\hline 11 & KONUT & $\begin{array}{l}\text { OTEL } \\
\text { (PROJE AŞAMASINDA }\end{array}$ \\
\hline 12 & KONUT & $\begin{array}{l}\text { OTEL } \\
\text { (PROJE AŞAMASINDA }\end{array}$ \\
\hline 13 & KONUT & OTEL \\
\hline
\end{tabular}

Tablo 2. Tescilli Anıt Eserler İle İlgili Kullanım Kararları Değişikliği

\begin{tabular}{|l|l|l|l|}
\hline $\begin{array}{l}\text { BINA } \\
\text { ENVANTER NO }\end{array}$ & ÍLK KULLANIM & ÍKINCI KULLANIM & GÜNCEL KULLANIM \\
\hline A82 & $\begin{array}{l}\text { ERMENI } \\
\text { PROTESTAN } \\
\text { KILISESI }\end{array}$ & $\begin{array}{l}\text { ISTIKLAL } \\
\text { İLKOKULU }\end{array}$ & $\begin{array}{l}\text { REHBERLIK ve } \\
\text { ARAŞTIRMA MERKEZI } \\
\text { MÜDÜRLÜĞ̈Ü }\end{array}$ \\
\hline A74 & SARNIÇ & SARNIÇ & $\begin{array}{l}\text { SARNIÇ ve PARK } \\
\text { (Sarnıç olarak Kullanılmıyor) }\end{array}$ \\
\hline A75 & $\begin{array}{l}\text { ZELIHA KADIN } \\
\text { ÇEŞMESi }\end{array}$ & $\begin{array}{l}\text { ÇEŞME } \\
\text { (ÇEŞME olarak kullanılmıyor) }\end{array}$ \\
\hline
\end{tabular}

\section{DEĞERLENDIRME VE SONUÇ}

Kocaeli ilinin merkez ilçesi olan İzmit ilçesinde yapılan bu çalışmada kentsel sit alanı olarak belirlenen bölgede özgün sokak dokusunun en iyi korunduğu Kapanca Sokağı özelinde, kimlik konusu doğal, yapay, sosyal çevre ve tarihsel süreç açısından ele alınmış ve incelenmiştir. Böylelikle Kapanca sokağının sahip olduğu, özgün tarihsel dokunun gelecek kuşaklara aktarılmasını mümkün kılmak amacıyla, bölgenin değerleri ve geçirdiği değişimler tespit edilmiştir. Çalışmada yapılan değerlendirmelere göre;

İzmit merkezinde bulunan ve 'Kapan Önü adı verilen ticari alana ulaşımın kolaylığı nedeniyle, dükkân sahiplerinin yaşadığı konutların bulunduğu bu sokak konum olarak ticari merkeze yürüme mesafesindedir. Sokakta yer alan konutların toprağa oturan bodrum veya zemin katları eğimden kaynaklı olarak yığma taş duvarlıdır. İzmit'te yaşanan iklimsel değişimlere yanıt verecek şekilde tasarlanan bu konutlar kırma çatılı ve bakıları manzara (İzmit Körfezi) ve güneye yöneliktir. Konutlar bahçeli olup, bahçelerinde çeşitli meyve ağaçları bulunmaktadır. İnşa edildikleri dönemde doğal çevre özellikleri ön planda tutulduğundan yapıların topografya ile uyumu son derece başarııdır. Bahsedilen özellikleri göz önüne alındığında Kapanca Sokak'ta doğal çevre verilerinin etkili olarak kullanıldığı açıktır.

Sokakta özgün fiziki yapı büyük ölçüde korunmuş, ancak sivil mimari örneği olan konutların çoğu rekonstrüksiyon yöntemi ile yeniden inşa edilmiştir. Sokaktaki 
konutların birbirlerine olan yakınlıkları, daha kesin sınırların oluşumunu sağlamakta ve gruplaşma eğilimi göstermektedir. Sokakta bulunan tescilli konutların çoğu sokağa dayalıdır. Binaların ardışık düzende ve aynı istikamette devam etmesi, bir bütün oluşturarak birlikte algılanmalarına sebep olmaktadır. Sokak boyunca yer alan parsellerin sürekliliği, konutların ve bahçe duvarlarının bir sınır oluşturması, konutların cephe özelliklerinden doluluk-boşluk oranları, girinti-çıkıntıları (cumbaları) ve malzemelerindeki benzerliklerinden dolayı, yerleşim tam bir sokak olarak algılanmaktadır.

Kent kimliği oluşumunun, geçmiş öğeler, geçmiş öğelerin yeniden yorumlanması ve yeni öğeler zincirinden oluşan, geçmişten geleceğe uzanan bir süreç olduğu düşünülürse; tarihi kent merkezinin içinde yer alan Kapanca Sokağı'nın kimlik anlamında geçmişten gelen çok önemli değerlere sahip olmasına rağmen, çevresinin çok katlı sıradan apartmanlarla sarıldığı ve algılanamaz durumda olduğu da bir gerçektir. Sonuç olarak yapay çevre, dik bir yokuş üzerinde inşa edilmiş olmasına rağmen algılanmaya müsait şekilde yapılanmıştır. Ancak daha sonraki yıllarda inşa edilen yapılar nedeniyle sokak içine girene kadar gizlenmiş ve algılanamaz konumdadır.

Akçakoca Mahallesi'nde son yüz yıldır adı değişmeyen Kapanca Sokağı'nın bu süreçte morfolojik yapısı, parselasyon durumu, sokak başlangıç ve bitiş noktası arasındaki kot farkı değişmemiş; dolayısıyla sokak dokusu çoğunlukla korunmuştur.

Geçmişte ana caddeden Çarşı-i Müslim Mahallesi'nde bulunan çarşıya yani Kapan Önü'ne geçiş yolu üzerinde bulunması nedeniyle adını konumundan alan Kapanca Sokak'ta, o dönemde yaya ulaşımının sıklıkla kullanıldığı ticaret ve konut alanlarının yakınlık ilişkisi ön planda tutulmuştur. Tarihi dokularımızdaki sokakları ayrıcalıklı kılan olgu, sokakları tanımlayan yapılar ile bu yapıların kullanıcıları arasında oluşan diyalektiktir. Sokakların oluşmasına neden olan bu diyalektik ilişkinin tutarlılığı kimliğin sürdürülebilmesinde önemli bir rol oynamaktadır. Ortaya çıkacak bozulmaların derecesine bağlı olarak, sokaklarda da kimliğin yitirilmesi söz konusu olmaktadır. Nitekim 2009 yılına kadar konutların çoğunlukta olduğu Kapanca sokaktaki binalar yakın zamanda gerçekleştirilen restorasyon ve rekonstrüksiyon çalışmaları ile, İzmit Belediyesi'nin Tarih Koridoru projesi kapsamında yeniden işlevlendirilerek kullanım amaçları değiştirilmiştir. Kullanıcıların değişimi ile özgün sosyo-kültürel kimliği kaybolmuştur. Geçmişte konut olan bu mekânların çoğu bugün derneklerin kullanımına verilmiştir. Bunun sonucunda, zaten çevresindeki yapılaşma yüzünden gizli kalmış olan bu sokak halkın gündelik yaşamından ve kullanımından oldukça uzaklaştırılmış duruma gelmiştir.

Tarihi değeri olan bir yer, kimliği ile tanındığından bu özelliğini yitirmemeli ve o yer de yapılacak değişikliklerin hangi şartlarda gerçekleşmesi gerektiği ve sonuçlarının neler olacağı sorgulanmalıdır. Bu nedenle çalışma alanı tarihsel süreç açısından da ele alınmış ve bellek aktarımı sorgulanmıştır. Belleğin bir yerin kimliğinin aktarımındaki önemi büyüktür. Geçmiş ve gelecek arasındaki bağları kurabilmenin yollarından birisi de belleğin aktarılabilmesidir. Ancak bu aktarımın eksiksiz yapılması ile bu sağlanabilecektir.

Yüzyıla yakın bir süre önce inşa edilen bu sokakta yapılan inceleme sonucunda o dönemde yapılaşmanın doğal bileşenler göz ardı edilmeden gerçekleştiği görülmektedir. Bunun sonucu olarak yerin oraya özgü olan biricikliği sağlanmıştır. Yapıların doğa ile ve sosyal durum ile uyumu sonucu ortaya çıkan konut tipleri, sokak üzerindeki yerleşimleri de bu duruma katkı sağlamaktadır. Sokağın kendi içindeki algılanabilirliği o yerde yaşayan insanların aidiyet hislerini güçlendirmektedir. Ancak, 
sokak bugün yapısal anlamda korunmaya çalışılsa da, kent içindeki varlığı hem algılanabilirlik hem de gündelik yaşamdan uzaklığı nedeniyle korunamamıştır. Dokusu değişmese de işlevi değişmiş ve anlamı boşaltılmıştır. Kentin gelişimi için yapılan planlamalar sokağı görünmez ve yaşanmaz hale getirmiştir. Böylesine önemli bir yerleşim alanı, kentin kimliği adına kullanılabilecek çek önemli verilere sahip olsa da bu durum göz ardı edilmektedir.

Bu nedenlerle, çalışma alanının ve bu alana benzer alanların en önemli yapısal kimlik elemanlarını oluşturan öğelerin dikkat çekiciliğini ve algılanabilirliklerini artırmak adına gerek yapı gerek donatı ölçeğinde gerekli düzenlemelere gidilmelidir. Etrafındaki aykırı yapılaşmalar iyileştirilmeli, aydınlatmalar, yönlendiriciler, bilgilendirme panoları ile tanımlanarak belirgin hale getirilmelidirler. Ranta dayalı fırsatlara yer verilmemeli ve kent bütününde doğaya ve tarihe saygılı bütüncül yaklaşımlarla kentin kimliği korunarak yaşatılmalıdır. Tarihi sokaklarda bulunan yapılar, dokuya uygun olarak iyileştirilmeli, bu sokaklarda mekânın tanınırlığının ve algılanabilirliğinin artırılması anlamında kent estetiğine ve işlevine katkıda bulunan, mekânın kimliği ile bütünleşen ve tarihi dokuya uygun donatı elemanları konumlandırımalıdır. Bellek mekân olarak kabul edilebilecek ve geçmiş yaşamların kanıtları olan tarihi sokaklar özenilerek korunmalı ve kent kimliği adına varlıkları incelenmelidir. Kentin planlamasında, yol gösterici nitelikteki bu yerlerin analizlerinden faydalanılmalıdır. Günümüz kentlerinde meydana gelen aynılaşma, küreselleşme ve kapitalizm sonucu oluşan benzerlik, bu tip bellek mekânların göz ardı edilişi sonucu meydana gelmektedir. Geçmişin izlerini sürmek geleceğin en iyi yol aydınlatıcılarıdır.

Bu çalışmada çalışma alanının bir sokak olarak ele alınması yaşanılan yer kavramının ancak ilişkiler sonucunda ortaya çıkacağı gerçeğidir. Mimarlık ürününü sadece tek yapı olarak ele almak yerine hem yapılar topluluğu olarak, hem de yapılar topluluğu ile tanımlanan ve birbirleri ile ilişkili mekânlar bütünü olarak ele almak önemlidir. Yerleşmeleri, yapıları ve mekânları karşılıklı ilişkileri içinde ve tümleşik ögeler olarak ele alan bir yaklaşım ile yere ait kimlik öğeleri anlaşılabilir ve anlatılabilir. Bu nedenle yerel kimlik üzerine yapılan bu çalışmada Kapanca Sokak ölçeğinde; doğal, yapay, tarihsel süreç, sosyo-kültürel bileşenler ve bunların birbirleri ile etkileşimleri ortaya koyulmuştur. Ancak ileride Kocaeli'nin kentsel kimliğini ortaya koymak için kent genelinde çok disiplinli çalışmalar yapmak gereklidir.

\section{KAYNAKLAR}

Adiloğlu, Fatoş, "Space and Place in Cinema", 4th International Symposium Communication in the Millenium içinde. TÜBiTAK Yayınları, 2006, s. 293-297.

Akcan, Nilgün, "Kapanca Sokak ve Sırrı Paşa Sözleşmesinin Gelişimi”, KMiM Dergisi, Eylül-Ekim-Kasım, Sayı 1. Kocaeli 2006, s. 28-29.

Alangoya, Kezban Ayça, "Genius Loci” Kavramı ve Mimarlık Eğitiminde Doğal ve Yapılı Çevre İlişkisi, Mimarlık Dergisi, 385, Eylül-Ekim 2015, s.n.y. http://www.mimarlikdergisi.com/index.cfm?sayfa=mimarlik\&DergiSayi=399\&ReclD=376 $\underline{0}$, Erişim Tarihi: 25.11.2016, Saat: 10:50.

Arabulan, Selin, Yer/Mekân Kimliğinin Değişimi: Mezitbey Hamamı ve Yakın Çevresi Alan Çalışması, Trakya Üniversitesi, Fen Bilimleri Enstitüsü, Yayınlanmamış Yüksek Lisans Tezi, Mimarlık Anabilim Dalı, Edirne 2008. 
Aytem, Nurdan Meltem, Mimari Mekân da Renk, Form ve Doku Değişkenlerinin Algılanması, İstanbul Teknik Üniversitesi Fen Bilimleri Enstitüsü, Yayınlanmamış Yüksek Lisans Tezi, İstanbul 2005.

Ayyıldız, Sonay; Özbayraktar, Mehtap, "Belleğini Arayan Kent: Bir Kentin Görün(mey)en Yüzü”, Tasarım Dergisi, Sayı 149, 2005, s. 34-37.

Bayramoğlu, Nergis, Kullanıcısı Algısı Bağlamında Kentsel Kimlik: Barbaros BulvarıBüyükdere Kentsel Aksı, İstanbul Teknik Üniversitesi Fen Bilimleri Enstitüsü, Yayınlanmamış Yüksek Lisans Tezi, İstanbul 2010.

Birol, Gaye, 2007, "Bir Kentin Kimliği ve Kervansaray Oteli Üzerine Bir Değerlendirme", Arkitekt Dergisi, Kasım-Aralık 2007, Sayı 514, s. 46-54.

Bölgesel Göstergeler TR42 Kocaeli, Sakarya, Düzce, Bolu, Yalova 2009, Türkiye İstatistik Kurumu Matbaası, "Genel Bilgiler", Ankara 2010, s. IX-X.

Ciravoğlu, Ayşen, Sürdürülebilirlik Düşüncesi-Mimarlık Etkileşimine Alternatif Bir Bakış: "Yer"in Çevre Bilincine Etkisi, Yıldız Teknik Üniversitesi Fen Bilimleri Enstitüsü, Mimarlık Anabilim Dalı, Yayınlanmamış Doktora Tezi, İstanbul 2006.

Coşkun, Lale Seval Biltekin, Kamusal Mekân Ve Kolektif Bellek Bağlamında Istasyon Binalarının Incelenmesi ve Hızlı Tren İstasyonlarına Dönüşümü, Yayınlanmamış Yüksek Lisans Tezi, Gazi Üniversitesi, Fen Bilimleri Enstitüsü, Ankara 2013.

Erdoğan, Nevnihal; Ayyıldız, Sonay; Özbayraktar, Mehtap, Tarihi İzmit Kent Merkezi Mahalleler Sokaklar Mimari Eserler, Kocaeli Büyükşehir Belediyesi Kültür Yayınları 20, İse Reklam, İstanbul 2011.

Erzen, Jale N., Üç Habitus-Yeryüzü, Kent, Yapı, Yapı Kredi Yayınları, İstanbul 2015.

Eyüce, Ahmet, Geleneksel Yapılar ve Mekân lar, Birsen Yayınevi, İstanbul 2005.

Harvey, David, Sosyal Adalet ve Şehir, Çev.: Mehmet Moralı, 1. Basım, 2003.

İzeyap Bülteni, Sayı 95/3, Doruk Basım Yayın, İzmit 1995. s. 16-17.

İmit Analitik Etüdleri, İller Bankası Harita Genel Müdürlüğü Matbaası Döner Sermayesi, Ankara 1970.

İzmit Belediyesi Emlak ve İstimlak Müdürlüğü Arşivi

İzmit Belediyesi Etüt Proje Müdürlüğü Arşivi

İzmit Belediyesi İmar ve Şehircilik Müdürlüğü Arşivi

Kocaeli II Yıllığı, “Doğal Yapı”, Atlan Matbaası, İzmit 2001.

Kösoglu, Nevzat, "Kültür/Kimlik Üzerine", Türkiye Günlüğü, Sayı 33, Mart / Nisan 1995, s. 43.

Kuyumcu, Yılmaz, "Kapanca'da” Şiiri, İeyap Bülteni, 1.Sayı, Doruk Basım Yayın Reklamcılık Ltd. Şti., İzmit 1994, s. 32. 
Lynch, Kevin, Kent İmgesi (The Image of the City, 1960), Çev.: İrem Başaran, VI. Basım, İş Bankası Kültür Yayınları, İstanbul, 2014.

Norberg-Schulz, Christian., Yer Kavramı Bağlamında Eski Yapılarda Yapılaşma, Çev.: İdil Üçer, Mimarlık Dergisi, Sayı 297, 2001, s. 42-43.

Önem, A. Buket; Kılınçaslan, İsmet, "Haliç Bölgesinde Çevre Algılama ve Kentsel Kimlik", ITÜ Dergisi/a, Mimarlık, Planlama ve Tasarım, Cilt 4, Sayı 1, Mart 2005, s.115124.

Özalp, Defne, Tarihi Kent Imajının Korunmasında Kentsel Tasarım-Antakya Örneği, T.C. Kültür ve Turizm Bakanlığı Kültür Varlıkları ve Müzeler Genel Müdürlüğü, Uzmanlık Tezi, Ankara 2008.

Ryden, Kent C., "Mapping The Invisible Landscape: Folklore, Writing, and the Sense of Place", The Annals of lowa, State Historical Society of lowa, lowa Department of Cultural Affairs, 54 (1995), s. 290-292.

Sharr, Adam, Mimarlar İçin Heidegger, Çev.: Volkan Atmaca, Birinci Baskı, Yem Yayınları, İstanbul 2013.

Şen, Nihal Polat, İmit'te Merkezi, Yerel Yönetim ve Sivil Toplum Örgütlerinin İşbirliği Ile Gerçekleştirilen İzeyap Projesi, Mimar Sinan Üniversitesi Mimarlık Fakültesi, Şehir ve Bölge Planlama Bölümü, Lisans Bitirme Ödevi, İstanbul 1996.

Topçu, Kadriye Deniz, "Kent Kimliği Üzerine Bir Araştırma: Konya Örneği", Uluslararası Insan Bilimleri Dergisi, Cilt:8, Sayı:2, 2011, s. 1052.

Tuğlacı, Pars, Okyanus Ansiklopedik Sözlük, Sermet Matbaası, Cilt III, 1. Baskı, İstanbul 1972, s. 1377-1379.

Tuncer, Ezgi, "Yer" Üzerine Bir Okuma Denemesi: Samatya ＂đæær-Kurma" Pratikleri, Yıldız Teknik Üniversitesi, Yayınlanmamış Doktora Tezi, İstanbul 2010.

Yayınoğlu, Pınar Eraslan; Susar, Filiz, Kent, Görsel Kimlik ve Iletişim, 1. Baskı, Umuttepe Yayınları No:3, Kocaeli 2008. 